\title{
THE EFFECT OF KNOWLEDGE OF ETHICS, RELIGIOSITY, ETHICAL SENSITIVITY, ETHICAL ORIENTATION TO ACCOUNTING STUDENTS PERCEPTION OF CREATIVE ACCOUNTING PRACTICES
}

\author{
Dede Sevi, Sri Mulyati, Asep Kurniawan \\ Sekolah Tinggi IImu Ekonomi Sutaatmadja Subang \\ Email: dedesevi52@gmail.com \\ Email: srimulyati82@gmai.com \\ Email: asep@stiesa.ac.id
}

INFO ARTIKEL

Histori Artikel :

Tgl. Masuk : 12-03-2021

Tgl. Diterima : 31-03-2021

Tersedia Online : 31-03-2021

Keywords:

Knowledge of Ethics, Religiosity,

Ethical Sensitivity, Ethical Orientation,

Accounting Students Perception Of

Creative Accounting Practices
ABSTRACT

Creative accounting is an ethical dilemma because it does not seem to violate the rules but causes users of financial statements to make wrong decisions. With the occurrence of various accounting scandals abroad and in Indonesia that have committed creative accounting actions, it is evident that there are still many accountants who violate the basic principles of professional accounting ethics and from creative accounting actions that have resulted in companies collapsing. This study aims to examine whether there is a relationship between ethical knowledge, religiosity, ethical sensitivity, and ethical orientation to accounting students' perceptions of creative accounting practices.

The subjects of this study were students of higher education accounting study programs in West Java. The research method used in this research is quantitative with a questionnaire. The survey was conducted on 320 respondents of higher education accounting students in West Java. The analysis technique uses multiple linear regression analysis with SPSS software.

The results of this study indicate that: ethical knowledge has a positive effect on accounting students' perceptions of creative accounting practices, religiosity has no effect on accounting students' perceptions of creative accounting practices, ethical sensitivity has a positive effect on accounting students' perceptions of creative accounting practices, ethical orientation has no effect on perceptions. accounting students regarding creative accounting practices. And simultaneously ethical knowledge, religiosity, ethical sensitivity, and ethical orientation affect the perceptions of accounting students regarding creative accounting practices as evidenced by the $F_{\text {value }}$ of 62.587> $F_{\text {table }} 2,4003$ and a significance value of $0,000<0.05$.

\section{PENDAHULUAN}

Dari sudut pandang ahli, akuntansi memiliki definisi yang berbeda. Secara umum, akuntansi adalah suatu aktivitas 
mencatat, menginterpretasikan data, dan melaporkan transaksi keuangan perusahaan untuk digunakan oleh pihakpihak yang berkepentingan dalam pengambilan keputusan ekonomi (Charles \& Walter, 2007; Renaldo, 2012; Roberts \& Scapens, 1985; Somantri, 2011). Berdasarkan Keputusan Menteri Keuangan Republik Indonesia (No. 476 KMK.01) pada tahun 1991, akuntansi adalah suatu proses pengumpulan, pencatatan, penganalisaan, peringkasan, pengklasifikasian dan pelaporan transaksi keuangan dari suatu kesatuan ekonomi untuk menyediakan informasi keuangan bagi para pemakai laporan untuk pengambilan keputusan. Akuntansi digunakan sebagai penyedia informasi keuangan perusahaan. Laporan keuangan di dalamnya terdapat posisi keuangan, kinerja dan perubahan posisi keuangan suatu perusahaan yang dapat digunakan sebagai bahan pertimbangan untuk pengambilan keputusan oleh para penggunanya.

Laporan keuangan disusun berdasarkan standar atau aturan yang berlaku. Standar akuntansi yang berlaku di Indonesia yaitu Pernyataan Standar Akuntansi Keuangan (PSAK). PSAK ini diterbitkan oleh Dewan Standar Akuntansi Keuangan - Ikatan Akuntan Indonesia (DSAK-IAI). PSAK merupakan pedoman umum dalam penyusunan laporan keuangan emiten dan perusahaan publik. PSAK berisi uraian materi yang di dalamnya mencakup hampir semua aspek yang berkaitan dengan akuntansi yang disusun oleh Ikatan Akuntan Indonesia (IAI). Standar akuntansi ini mengacu pada International Financial Reporting Standards (IFRS) yang telah diadopsi di Indonesia. IFRS membuat lingkungan akuntansi menjadi lebih kompleks, serta aturan akuntansi menjadi lebih fleksibel karena standar akuntansi IFRS berbasis principalbased atau mengatur hal - hal yang utama saja. Fleksibilitas standar akuntansi merupakan salah satu pendorong terjadinya creative accounting (Largay, 2002) dalam (Intan S, 2017). Hal ini yang membuat akuntan yang bekerja di sebuah perusahaan mendapat kebebasan dalam memilih metode akuntansi yang digunakan untuk menyusun laporan keuangan.
Bahkan dengan adanya PSAK sebagai standar pelaporan keuangan, nyatanya beberapa perusahaan masih belum memenuhi standar yang berlaku dalam penyusunan laporan keuangan. Tujuannya untuk memanipulasi data atau laporan keuangan perusahaan untuk meningkatkan kinerja perusahaan dan membentuk citra yang baik dalam laporan keuangannya, sehingga investor dan kreditor tertarik untuk berinvestasi. Dengan kata lain, pihak yang berwenang menyusun laporan keuangan melakukan tindakan creative accounting (Cinthia, 2019).

Tindakan creative accounting dapat didefinisikan sebagai proses di mana akuntan menggunakan pengetahuan dan pengalaman mereka tentang standar akuntansi untuk memanipulasi angka yang dilaporkan dalam laporan keuangan. Menurut Agustia dan Palupi (2012) praktik creative accounting adalah suatu proses pelaporan keuangan yang di dalamnya terdapat campur tangan manajer yang bertujuan untuk menguntungkan diri sendiri. Dan menurut Sulistiawan (2006) creative accounting merupakan usaha organisasi atau badan usaha untuk memanfaatkan teknik dan kebijakan akuntansi guna mendapatkan hasil yang diinginkan. Creative accounting ini masih kontroversial karena dilema etika yang harus dipertimbangkan oleh akuntan profesional ketika menggunakan metode-metode yang digunakan dalam laporan keuangan, karena sesungguhnya praktik creative accounting tidak melanggar aturan hukum dan Standar Akuntansi, namun creative accounting ini bisa menimbulkan misrepresentasi laporan keuangan (Usurelu et al, 2010).

Praktik creative accounting hingga saat ini masih menimbulkan berbagai pendapat dan perdebatan. Beberapa peneliti menyimpulkan bahwa praktik akuntansi kreatif adalah tindakan yang negatif. Karena praktik creative accounting dianggap sebagai praktik tidak etis dengan cara memanipulasi laporan keuangan yang akan mengurangi keandalan informasi keuangan didalam laporan keuangan tersebut. Odia dan Ogiedu (2013) juga berpendapat bahwa teknik yang digunakan dalam praktik creative accounting dilakukan dengan cara menyampaikan dan memberikan informasi 
yang salah untuk menyesatkan para pengguna laporan perusahaan sehingga hal ini memiliki kecenderungan pada tindakan penipuan. Dan menurut Sulistiawan (2006) berpendapat bahwa praktik creative accounting dianggap sebagai tindakan yang tidak etis, bahkan suatu bentuk dari manipulasi informasi yang menyesatkan penggunanya.

Selain itu, beberapa peneliti memiliki pendapat yang berbeda mengenai praktik creative accounting. Balaciu dan Pop (2008) menyimpulkan bahwa praktik creative accounting bukanlah sebuah tindakan kecurangan, hal tersebut bergantung pada masalah sudut pandang seseorang dan terjadi karena adanya celah yang ada dalam standar keuangan. Pendapat yang sama juga dikemukakan oleh Kaminski (2014) bahwa selama praktik creative accounting tidak melewati batas legal, maka hal tersebut tidak termasuk dalam tindakan kriminal karena merupakan tindakan yang legal, praktik creative accounting tersebut justru dapat memberikan keuntungan bagi perusahaan dalam jangka waktu yang panjang.

Skandal akuntansi yang terjadi di beberapa perusahaan maupun lembaga pemerintahan tidak lepas dari peran seorang profesi akuntan. Hal tersebut menyebabkan kepercayaan dan pandangan masyarakat terhadap profesi akuntan menjadi negatif dan membuat creative accounting menjadi perhatian publik. Skandal akuntansi yang sangat terkenal adalah kasus Enron. Enron melakukan manipulasi angka-angka pada pengungkapan laporan keuangan pada periode 1997 sampai dengan 2000 dengan melakukan penggelembungan (mark up) atas pendapatan sebesar $\$ 600$ juta dan menyembunyikan utangnya sebesar $\$ 1,2$ miliar. Hal tersebut dilakukan oleh manajemen Enron dengan tujuan mempertahankan kepercayaan pemegang saham sehingga membuat harga saham tetap tinggi. Kasus Enron tersebut melibatkan salah satu KAP The Big Five Arthur Andersen dalam memanipulasi laporan keuangannya. Enron telah melanggar etika dalam bisnis dengan melakukan manipulasi-manipulasi guna menarik investor. Sedangkan Arthur Andersen yang bertindak sebagai auditor pun telah melanggar etika profesinya sebagai seorang akuntan. Arthur Andersen telah melakukan "kerjasama" dalam memanipulasi laporan keuangan enron. Hal ini jelas Arthur Andersen tidak bersikap independent sebagaimana yang seharusnya sebagai seorang akuntan (https://jordyayal.wordpress.com, 2016).

Kasus serupa juga terjadi di Indonesia yaitu megaskandal PT Jiwasraya. Direktur Keuangan Jiwasraya periode 20082018 Hary Prasetyo mengakui bahwa dirinya bersama mantan Direktur Utama Jiwasraya Hendrisman Rahim telah melakukan manipulasi laporan keuangan atau window dressing sejak pertama kali ia memimpin PT Jiwasraya pada 2008. Praktik manipulasi laporan keuangan tersebut, dilakukan atas sepengetahuan jajaran Kementerian BUMN selaku pemegang saham dan Otoritas Jasa Keuangan (OJK). Tujuannya agar manajemen Jiwasraya kala itu dapat melakukan reasuransi serta menerbitkan produk JS Proteksi Plan yang memiliki skema "ponzi". Produk itu yang akhirnya menjadikan Jiwasraya dan negara merugi, besarnya kerugian negara mencapai Rp 16,8 triliun yang berasal dari penyidikan atas berkas selama 10 tahun, dari 2008 hingga 2018. Padahal keuangan perusahaan pelat merah itu tergolong bagus bila dilihat dari laporan keuangannya dalam beberapa tahun kebelakang (https://sumsel.antaranews.com).

Kasus-kasus tersebut memberikan bukti bahwa masih banyak akuntan yang melanggar prinsip dasar etika profesi akuntan dan dari tindakan creative accounting mengakibatkan perusahaan runtuh. Hal ini menyadarkan pentingnya pengetahuan etika sebelum mahasiswa Akuntansi terjun ke dalam dunia akuntan. Pengetahuan mahasiswa khususnya tentang etika profesi akuntan akan menjadi modal bagi mahasiswa akuntansi saat akan menjadi seorang akuntan (Aprin, 2018). Menurut Mandarwati (2014) dalam Cinthia (2019) menyatakan bahwa pengetahuan etika berpengaruh terhadap persepsi mahasiswa akuntansi karena dengan pengetahuan etika yang dimiliki oleh mahasiswa akuntansi akan memberikan informasi-informasi tentang aturan etika seorang akuntan. Oleh karena itu, seseorang yang memiliki pengetahuan 
etika akan cenderung bertindak sesuai dengan kode etik yang diketahuinya.

Maryani dan Ludigdo (2001) menyatakan bahwa salah satu faktor yang dominan mempengaruhi sikap dan perilaku etis seseorang adalah religiusitas. Penelitian yang dilakukan oleh Hutahahean dan Hasnawati (2015) menyatakan bahwa, "keyakinan agama seseorang memberikan peranan penting dalam pengambilan keputusan etis. Dengan begitu seseorang yang memiliki tingkat Religiusitas yang tinggi akan mempertimbangkan segala perilakunya sesuai ajaran agama yang dianutnya."

Setiap individu pasti mempunyai kesadaran atau sensitivitas terhadap etika. Terutama mahasiswa akuntansi yang telah mendapatkan mata kuliah etika bisnis diperkuliahannya. Namun kesadaran terhadap etika tersebut pada setiap orang itu pasti berbeda-beda. Perbedaan tersebut akan mempengaruhi persepsi seseorang dalam berperilaku etis. Sensitivitas etis mempengaruhi seseorang untuk mengambil keputusan dan melakukan tindakan Dengan mempertimbangkan nilainilai etika. Sensitivitas etika ini sangat penting keberadaannya untuk menentukan tingkat kepekaan seseorang terhadap nilainilai etika yang terjadi baik di dalam ataupun di luar lingkungan mereka (Ferdinandus, 2016).

Faktor lain yang dapat mempengaruhi persepsi seseorang mengenai creative accounting yaitu orientasi etis. Orientasi etis atau nilai-nilai etika ini dikendalikan oleh karakteristik idealisme dan relativisme. Idealisme mengacu pada hal yang dipercaya oleh individu dengan apa yang dimiliki dan diinginkannya tidak melanggar nilai-nilai moral. Seorang individu yang idealist akan menghindari berbagai tindakan yang dapat menyakiti maupun merugikan orang disekitarnya, seorang idealist akan mengambil tindakan tegas terhadap suatu kejadian yang tidak etis ataupun yang akan merugikan orang lain (Mella, 2015). Sedangkan relativisme adalah suatu sikap penolakan terhadap nilai-nilai moral yang absolut dalam mengarahkan perilaku etis (Falah, 2006). Seorang individu relativis mengabaikan prinsip-prinsip yang ada dan lebih melihat keadaan sekitar sebelum akhirnya bertindak untuk merespon suatu kejadian yang melanggar etika (Mella, 2015). Mahasiswa yang memiliki karakteristik individu idealisme ataupun relativisme, masing-masing akan memiliki pengaruh terhadap persepsinya mengenai creative accounting yang terjadi.

Research gap pada penelitian ini adalah variabel pengetahuan etika. Dalam penelitian Mirna \& Bambang (2016) menyatakan bahwa variabel pengetahuan atau pendidikan etika bisnis tidak memiliki pengaruh yang signifikan terhadap persepsi etis mahasiwa/i akuntansi, sedangkan pada penelitian Aprin (2018) menyatakan bahwa variabel pengetahuan etika berpengaruh positif terhadap Persepsi Mahasiswa Akuntansi mengenai Praktik Creative accounting. Adapun research gap pada variabel orientasi etis, terdapat pada penelitian Dodik, M.Bavana \& M.lqbal (2019) yang menyebutkan bahwa variabel orientasi etis tidak berpengaruh terhadap persepsi mahasiswa tentang akuntansi kreatif. Pada penelitian Intan S (2017) juga menyebutkan bahwa variabel orientasi etis tidak berpengaruh terhadap Persepsi Mahasiswa Akuntansi mengenai Praktik Creative accounting dan juga pada penelitian Maria (2017) menyebutkan bahwa variabel orientasi etis tidak berpengaruh terhadap Persepsi Etis Mahasiswa Akuntansi mengenai Praktik Creative accounting. Namun pada penelitian Intan P \& Sukirno (2020) menyebutkan bahwa variabel orientasi etis berpengaruh terhadap Persepsi Mahasiswa Akuntansi tentang Akuntansi Kreatif. Pada penelitian Chintia (2019) menyebutkan bahwa orientasi etis berpengaruh positif dan signifikan terhadap persepsi mahasiswa akuntansi mengenai creative accounting. Dan pada penelitian May D \& Dr. Ratna (2017) menyebutkan bahwa variabel orientasi etis berpengaruh terhadap Persepsi Mahasiswa Akuntansi mengenai Creative accounting.

Dari hasil penelitian sebelumnya, menunjukkan bahwa adanya ketidakkonsistenan hasil (Research gap) terutama untuk variabel pengetahuan etika dan orientasi etis. Berdasarkan hasil temuan tersebut, maka dari itu dalam penelitian ini, peneliti hendak melakukan pengujian kembali pengaruh dari 
pengetahuan etika dan orientasi etis terhadap persepsi mahasiswa akuntansi mengenai praktik creative accounting. dan variabel berikutnya yang akan dilakukan pengujian kembali yaitu religiusitas dan sensitivitas etis.

Perbedaan penelitian ini dengan penelitian sebelumnya, yaitu menggunakan variabel penelitian yang dilakukan oleh Aprin (2018) yang berupa variabel pengetahuan etika, religiusitas, dan sensitivitas etis lalu menambahkah variabel orientasi etis. Pada penelitian ini tidak membandingkan persepsi mahasiswa akuntansi fakultas ekonomi Universitas Negeri Yogyakarta dan Universitas negeri berbasis keagamaan seperti yang dilakukan oleh penelitian Aprin (2018). Subjek penelitian ini yaitu mahasiswa program studi akuntansi perguruan tinggi di Jawa Barat.

Berdasarkan uraian dan fenomena diatas, maka penulis tertarik untuk mengambil judul "Pengaruh Pengetahuan Etika, Religiusitas, Sensitivitas Etis, dan Orientasi Etis Terhadap Persepsi Mahasiswa Akuntansi Mengenai Praktik Creative accounting (Studi Kasus pada Mahasiswa Akuntansi Perguruan Tinggi di Jawa Barat)".

\section{KERANGKA TEORITIS DAN PENGEMBANGAN HIPOTESIS}

\section{Teori Atribusi}

Teori atribusi mempelajari proses bagaimana seseorang menginterpresentasikan suatu peristiwa, alasan, atau sebab perilakunya. Teori ini dikembangkan oleh Fritz Heider yang berargumentasi bahwa perilaku seseorang ditentukan oleh kombinasi antara kekuatan internal, yaitu faktor-faktor yang berasal dari dalam diri seseorang, seperti faktor kemampuan atau usaha dan kekuatan eksternal yaitu faktor-faktor yang berasal dari luar, seperti kesulitan dalam pekerjaan atau keberuntungan (Arfan Ikhsan, 2011).

\section{Persepsi Mahasiswa Akuntansi Mengenai Praktik Creative Accounting}

Persepsi memungkinkan setiap orang berpikir dan memberikan suatu rangsangan sesuai dengan situasi dan keadaan yang melingkupinya (Maria Yolanda, 2017). Mahasiswa akuntansi sebagai para calon profesional dimasa depan dan dengan pendidikan etika yang sudah diketahuinya dijenjang perkuliahan dapat menguntungkan profesinya dalam jangka panjang. Namun Setiap mahasiswa pasti mempunyai persepsi moral, penalaran, dan perilaku yang berbeda-beda, meskipun telah diberikan pendidikan etika dengan porsi yang sama di jenjang perkuliahan. Dengan berbagai skandal etis yang terjadi baik luar negeri maupun di Indonesia yang melibatkan profesi akuntan, mahasiswa akuntansi diharapkan memberikan tanggapan dan persepsi dari calon akuntan yakni mahasiswa akuntansi penting untuk diketahui, karena mahasiswa akuntansi merupakan masa depan profesi tersebut.

\section{Pengetahuan Etika}

Dalam Kamus Besar Bahasa Indonesia, Etika Adalah ilmu tentang apa yang baik dan apa yang buruk dan tentang hak dan kewajiban moral (akhlak). Etika sangat erat kaitannya dengan hubungan yang mendasar antar manusia dan berfungsi untuk mengarahkan dan membentuk perilaku moral manusia. Moralitas sangat erat kaitannya dengan hubungan dasar antar manusia dan dapat membimbing serta membentuk perilaku moral masyarakat. Moralitas adalah sikap spiritual dan emosional seorang individu sebagai anggota suatu kelompok sosial yang menjalankan tugas atau fungsi yang diminta oleh kelompok dan loyalitas kepada kelompoknya (Maria Yolanda, 2017).

Etika tidak hanya ada dalam kehidupan sosial, tetapi etika juga ada dalam dunia pekerjaan untuk mengatur mereka yang memiliki profesi. etika ini lah yang disebut etika profesi. Priambudi (2016) mengungkapkan etika profesi disepakati secara bersama oleh anggotanya disebut kode etik. Kode etik terdiri dari aturanaturan yang harus dijalankan oleh anggota suatu profesi.

Etika profesi akuntan di Indonesia diatur dalam kode etik akuntan Indonesia. Tujuan dari kode etik Akuntan adalah untuk bertanggung jawab kepada Pengguna jasa. Etika profesi akuntansi ini berisi tentang pedoman dasar penyusunan kode etik yang disusun dan disahkan oleh Ikatan Akuntan 
Inonesia (IAI). Indiana dan Sri (2006) dalam Aprin (2018) menyebutkan bahwa Kode Etik Akuntan Indonesia yang disahkan pada Prodising Kongres VIII tahun 1998, terdiri dari empat bagian yaitu:

1. Kode Etik Umum

Terdiri dari 8 prinsip etika profesi, yang merupakan landasan perilaku etika profesional, memberikan kerangka dasar bagi aturan etika, dan mengatur pelaksanaan pemberian jasa profesional oleh anggota yang meliputi: tanggung jawab profesi, kepentingan umum, integritas, obyektifitas, kompetensi dan kehati-hatian profesionalnya, kerahasian, perilaku profesional, dan standar teknis.

2. Kode Etik Akuntan Kompartemen Kode Etik Akuntan Kompartemen disahkan oleh Rapat Anggota Kompartemen dan mengikat seluruh anggota Kompartemen yang bersangkutan.

3. Interpretasi Kode Etik Akuntan

Kompartemen Interpretasi Kode Etik Akuntan Kompartemen merupakan panduan penerapan Kode Etik Akuntan Kompartemen.

4. Pernyataan Etika Profesi yang berlaku saat itu dapat dipakai sebagai interpretasi dan atau aturan etika sampai dikeluarkannya aturan dan interpretasi baru untuk menggantikannya.

Pengetahuan etika yang dimaksud dalam penelitian ini adalah pengetahuan etika yang diketahui oleh mahasiswa akuntansi tentang kode etik akuntan. pentingnya untuk mengetahui dan memahami kode etik akuntan, yang digunakan sebagai bekal bagi mahasiswa akuntansi untuk berkarir di bidang profesi akuntan nanti. Karna mahasiswa akuntansi sebagai penerus profesi tersebut.

\section{Religiusitas}

Religiusitas berasal dari kata "religi" yang dalam Kamus Besar Bahasa Indonesia (KBBI) berarti kepercayaan terhadap Tuhan. Religiusitas sangat erat kaitannya dengan perilaku etis seseorang. Religiusitas menegaskan pada seberapa jauh kaitan antara manusia dengan Tuhannya (ilmu agama yang dianut). Menurut Pemayun dan Budiasih (2018) dalam Ayu Anjarwati (2019): "Religiusitas merupakan tingkat kepercayaan atau nilai agama yang dianut seseorang."

Jalaluddin (2011) mendefinisikan Religiusitas sebagai integritas kompleks antara pengetahuan manusia, perasaan, dan perilaku beragama. la juga mengemukakan bahwa keyakinan kepada agama dan perilaku religius merupakan konsistensi antara keyakinan sebagai elemen kognitif dan perasaan sebagai elemen emosional.

\section{Sensitivitas Etis}

Perilaku etis seorang profesional sangat dibutuhkan. seorang profesional memiliki keterampilan etika yang sangat tinggi dipengaruhi oleh kepekaan pribadi terhadap etika. Pada saat yang sama, faktor penting dalam mengevaluasi perilaku etis adalah keberadaan Individu menyadari bahwa dia adalah agen moral (Kartika, 2013). Namun, kesadaran setiap orang tentu berbeda, termasuk kesadaran akan perilaku etis. kemampuan seseorang untuk menyadari nilai-nilai moral keputusan disebut sensitivitas etis (Valasque Dan Rostankowski, 1985; Katika, 2013). Sensitivitas Etika adalah kemampuan untuk mengetahui sifat dasar pengambilan suatu keputusan apakah telah sesuai dengan etika yang ada atau belum (Ferdinandus Rio, 2016).

\section{Orientasi Etis}

Orientasi etis merupakan suatu alternatif perilaku seseorang untuk menyelesaikan dilema etika dan konsekuensi yang diharapkan oleh fungsi yang berbeda. Perilaku etis seseorang ditentukan oleh konsep diri pada masingmasing individu sesuai dengan peran yang disandangnya (Khomsiyah dan Indriantoro, 1998) dalam Maria (2017). Orientasi etis pada masing-masing individu ditentukan oleh kebutuhannya. Kebutuhan tersebut kemudian dipengaruhi dengan pengalaman pribadi dan sistem nilai individu yang akan menentukan suatu harapan atau tujuan dalam setiap perlakuannya sehingga pada akhirnya individu tersebut menentukan tindakan apa yang akan diambilnya (Maria, 2017).

$$
\text { Menurut Forsyth (1980) dalam Mulyana }
$$

Sari (2015) bahwa orientasi etis


dikendalikan oleh dua karakteristik, yaitu idealisme dan relativisme. Idealisme merupakan sikap yang dimiliki oleh individu yang menganggap bahwa suatu tindakan dikatakan benar apabila sesuai dengan kode etik umum yang berlaku. Sedangkan, relativisme menganggap bahwa aturan etika sifatnya tidak universal karena etika dilatar belakangi oleh budaya yang berbeda-beda.

\section{Pengembangan Hipotesis}

\section{Pengaruh Pengetahuan Etika Terhadap Persepsi Mahasiswa Akuntansi Mengenai Praktik Creative Accounting}

Pengetahuan merupakan segala informasi yang dimiliki atau diketahui secara sadar atau tidak. Pengetahuan juga bisa didapat seseorang melalui pengamatan akal atau panca indera. Pengetahuan yang dimaksud disini, berkaitan dengan prinsip etika yang berlaku dalam profesi akuntan atau kode etik akuntan.

Pengetahuan yang dimiliki setiap mahasiswa tentunya akan berbeda-beda. Mahasiswa tingkat atas pada umumnya memiliki pengetahuan yang lebih luas dan lebih memadai dibanding mahasiswa tingkat bawah, meskipun pengetahuan tersebut juga dapat ditentukan oleh besarnya usaha dan kemampuan masingmasing mahasiswa. Semakin luas dan banyak pengetahuan yang dimiliki mahasiswa mengenai prinsip etika profesi akuntan maka dapat membantu mereka untuk memberikan persepsi maupun tanggapan terhadap praktik creative accounting dibanding mahasiswa yang memiliki sedikit pengetahuan mengenai etika profesi akuntan.

Berdasarkan penelitian yang dilakukan oleh Aprin (2018) dan Septi (2017) menunjukkan bahwa pengetahuan etika berpengaruh positif terhadap persepsi mahasiswa akuntansi mengenai praktik creative accounting. Semakin tinggi pengetahuan etika profesi akuntan maka persepsi mahasiswa akuntansi mengenai creative accounting semakin tidak etis, sehingga mahasiswa akuntansi memberikan opini ketidaksetujuan dalam menyikapi creative accounting dan menganggap bahwa creative accounting merupakan tindakan yang tidak sesuai dengan etika profesi akuntan yang ada. Maka dapat dirumuskan hipotesis sebagai berikut:

$\mathrm{H}_{1}$ : Pengetahuan etika berpengaruh positif terhadap persepsi mahasiswa akuntansi mengenai praktik creative accounting

\section{Pengaruh Religiusitas Terhadap Persepsi Mahasiswa Akuntansi Mengenai Praktik Creative Accounting}

Religiusitas merupakan tingkat keyakinan seseorang yang spesifik dalam nilai-nilai agama yang dipraktekkan seorang individu di kehidupannya (Kharismawati, 2019). Keyakinan agama seorang memberikan peranan penting dalam pengambilan keputusan etis. Dengan begitu seseorang yang mempunyai religiusitas yang tinggi akan memikirkan segala perilakunya sesuai ajaran agama yang dianutnya. Religiusitas juga berhubungan langsung dengan agama, gaya hidup, kepercayaan, dan Tuhan yang mengatur alam semesta.

Setiap agama pasti mempunyai larangan serta ketentuan tentang perbuatan yang tidak etis. Memberikan arahan kapada manusia untuk berbuat baik. Kepercayaan seseorang terhadap agama yang dianutnya bisa menghindari sikap tidak etis. Sehingga, seseorang yang mempunyai religiusitas yang tinggi memiliki kendali diri yang baik.

Bedasarkan penelitian yang dilakukan oleh Aprin (2018) dan Intan Purnama (2019) menunjukkan bahwa religiusitas berpengaruh positif terhadap persepsi mahasiswa akuntansi mengenai praktik creative accounting. Semakin tinggi religiusitas yang dimiliki oleh seorang mahasiswa akuntansi, maka semakin tinggi pula mahasiswa akuntansi menganggap bahwa praktik creative accounting merupakan tindakan yang tidak etis. Berdasarkan uraian diatas, maka dapat dirumuskan hipotesis sebagai berikut:

$\mathrm{H}_{2}$ : Religiusitas berpengaruh positif terhadap persepsi mahasiswa akuntansi mengenai praktik creative accounting

Pengaruh Sensitivitas Etis Terhadap Persepsi Mahasiswa Akuntansi Mengenai Praktik Creative Accounting 
Menurut Anggi Ayu (2018) sensitivitas etis merupakan pengidentifikasian sebuah situasi moral, mengambil peran, menafsirkan masalah dan menyadari bahwa ada masalah moral. Setiap individu memiliki tingkat sensitivitas masing-masing, hal tersebut dikarenakan kesadaran untuk berperilaku etis pada setiap orang berbedabeda. Perbedaan tersebut akan mempengaruhi persepsi seseorang dalam berperilaku etis. Sensitivitas etis dapat mempengaruhi seseorang dalam membuat keputusan dan bertindak dengan mempertimbangkan nilai-nilai etika. Mahasiswa yang memiliki tingkat Sensitivitas Etis tinggi akan lebih mudah untuk mengenali dan mengambil pelajaran bahkan cenderung akan menghindari kasus-kasus mengenai praktik creative accounting.

Bedasarkan penelitian yang dilakukan oleh Aprin Asprilliadita (2018) menunjukkan bahwa sensitivitas etis berpengaruh positif terhadap persepsi mahasiswa akuntansi mengenai praktik creative accounting. Semakin tinggi sensitivitas etis yang dimiliki oleh seorang mahasiswa akuntansi, maka semakin tinggi pula mahasiswa akuntansi menganggap bahwa praktik creative accounting merupakan tindakan yang tidak etis. Berdasarkan uraian diatas, maka dapat dirumuskan hipotesis sebagai berikut:

$\mathrm{H}_{3}$ : Sensitivitas etis berpengaruh positif terhadap persepsi mahasiswa kuntansi mengenai praktik creative accounting

\section{Pengaruh Orientasi Etis Terhadap Persepsi Mahasiswa Akuntansi Mengenai Praktik Creative Accounting}

Orientasi Etis adalah suatu dasar pemikiran dalam menentukan sikap dan arah secara tepat dan benar mengenai dilema etis. Setiap mahasiswa mempunyai persepsi moral, penalaran, dan perilaku yang berbeda - beda antara yang satu dengan yang lainnya, meskipun mereka telah diberikan pendidikan etika dengan porsi yang sama (Smith, 2009) dalam Intan Saputri (2017).

Orientasi etis dibagi menjadi dua karakteristik yaitu idealisme dan relativisme. Idealisme merupakan sikap yang dimiliki oleh individu yang menganggap bahwa suatu tindakan dikatakan benar apabila sesuai dengan kode etik umum yang berlaku. Sedangkan, relativisme justru tidak mengindahkan prinsip-prinsip yang ada dan lebih melihat keadaan sekitar sebelum akhirnya bertindak atau merespon suatu kejadian yang melanggar etika.

Mahasiswa yang memiliki idealisme tinggi cenderung memberikan persepsi negatif terhadap suatu skandal yang terjadi di dalam profesi yang berkaitan dengan bidang akuntansi, sehingga idealisme akan menolak atau memberikan tanggapan atas ketidak setujuan atas praktik creative accounting. Sedangkan mahasiswa yang memiliki relativisme yang tinggi cenderung memberikan presepsi positif terhadap suatu skandal yang terjadi di dalam profesi yang berkaitan dengan akuntansi, sehingga relativisme akan setuju terhadap praktik creative accounting.

Berdasarkan penelitian yang dilakukan oleh Intan Purnama (2019) menunjukkan bahwa orientasi etika berpengaruh terhadap persepsi etis mahasiswa akuntansi mengenai creative accounting. Semakin tinggi orientasi etis mahasiswa maka semakin tinggi pula mahasiswa akuntansi menganggap bahwa praktik creative accounting merupakan tindakan yang tidak etis. Berdasarkan uraian diatas, maka dapat dirumuskan hipotesis sebagai berikut:

$\mathrm{H}_{4}$ : Orientasi Etis berpengaruh positif terhadap persepsi mahasiswa akuntansi mengenai praktik creative accounting

\section{Pengaruh Pengetahuan Etika, Religiusitas, Sensitivitas Etis, dan Orientasi Etis Terhadap Persepsi Mahasiswa Akuntansi Mengenai Praktik Creative Accounting}

Pengaruh pengetahuan etika, religiusitas, sensitivitas etis, dan orientasi etis dalam penelitian ini didasari oleh teori atribusi dan didukung oleh penelitian terdahulu. Setelah dilakukan pengujian secara parsial terhadap ke empat faktor tersebut, kemudian dilakukan secara simultan atau secara bersama-sama. Maka berdasarkan hal tersebut dapat dirumuskan hipotesis sebagai berikut:

$\mathrm{H}_{5}$ : Pengetahuan etika, religiusitas, sensitivitas etis, dan orientasi etis 
berpengaruh positif terhadap persepsi mahasiswa akuntansi mengenai praktik creative accounting

\section{Kerangka Hipotesis}

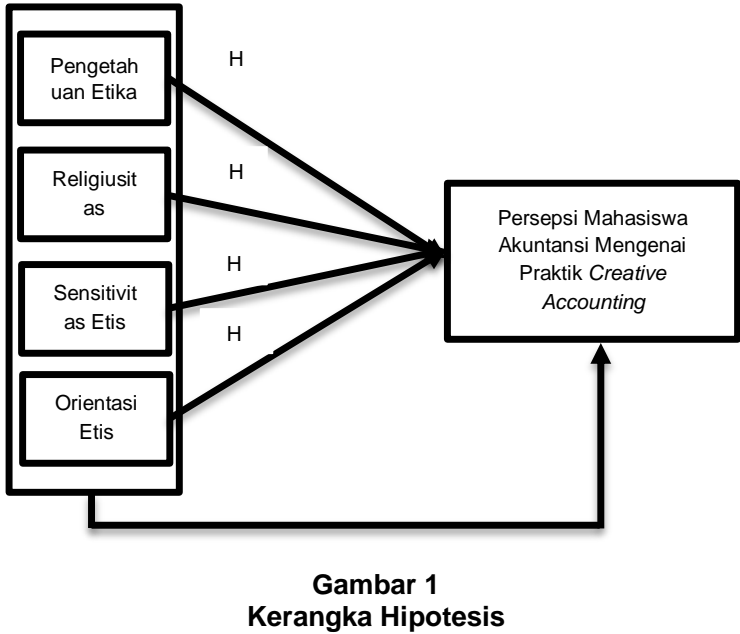

\section{METODOLOGI PENELITIAN}

Penelitian ini menggunakan penelitian kuantitatif. Penelitian kuantitatif adalah suatu proses menemukan pengetahuan yang menggunakan data berupa angka sebagai alat menganalisis keterangan mengenai apa yang ingin diketahui. (Kasiram, 2008). Penyajian penelitian ini menggunakan pola deskriptif. Pola deskriptif adalah metode penelitian yang menjelaskan suatu objek tertentu berdasarkan fakta dan apa adanya (Doddy, 2017).

\section{Populasi dan Sampel}

Menurut Sugiyono (2016): "Populasi adalah wilayah generalisasi yang terdiri atas obyek atau subyek yang mempunyai kualitas dan karakteristik tertentu yang ditetapkan oleh peneliti untuk dipelajari dan kemudian ditarik kesimpulan". Populasi dalam penelitian ini adalah Mahasiswa program studi akuntansi Perguruan Tinggi di Jawa Barat.

Sedangkan sampel menurut Sugiyono (2016) adalah bagian dari jumlah dan karakteristik yang dimiliki oleh populasi tersebut. Apabila populasinya besar, maka peneliti tidak mungkin untuk mempelajari semua yang ada pada populasi. Baik itu karena keterbatasan dana, waktu, maupun tenaga. Maka peneliti dapat menggunakan sampel yang diambil dari populasi. Sampel yang diambil oleh peneliti harus betul-betul mewakili populasi. Penentuan sampel dalam penelitian ini menggunakan acuan penentuan sampel menurut Roscoe (1975) yang dikutip Uma Sekaran (2006) yaitu lebih dari 30 dan kurang dari 500 responden.

\section{Teknik Pengambilan Sampel}

Teknik yang digunakan dalam pengambilan sampel pada penelitian ini yaitu Nonprobability sampling dengan menggunakan teknik Sampling purposive. Purposive sampling adalah teknik penentuan sampel berdasarkan atas ciri-ciri atau sifat-sifat tertentu (Trenggonowati, 2009:68). Kriteria sampel yang digunakan dalam penelitian ini yaitu:

1. Mahasiswa program studi akuntansi Perguruan Tinggi di Jawa Barat.

2. Telah atau sedang menempuh mata kuliah Akuntansi Keuangan, Etika Bisnis dan Pengauditan (dengan minimal telah atau sedang menempuh 2 mata kuliah).

\section{Sumber Data}

Sumber data yang digunakan dalam penelitian ini adalah sumber primer, Menurut Sugiyono (2016:137) "sumber primer adalah sumber data yang langsung memberikan data kepada pengumpul data". Data primer tersebut diperoleh dari hasil menyebarkan kuesioner yang dilakukan kepada pihak-pihak yang berhubungan dengan penelitian yang dilakukan.

\section{Teknik Pengumpulan Data}

Metode pengumpulan data yang digunakan dalam penelitian ini adalah dengan cara survey analitis. Survey analitis tersebut dilakukan melalui pertanyaan yang diajukan dalam kuesioner. Menurut Sugiyono (2016:142) "kuesioner merupakan teknik pengumpulan data yang dilakukan dengan cara memberi seperangkat pertanyaan tertulis kepada responden untuk dijawab." Pertanyaan yang diajukan dalam kuesioner bersifat pertanyaan tertutup, responden diminta memilih suatu jawaban dari suatu daftar jawaban yang disediakan. 


\section{Definisi dan Operasionalisasi Variabel}

\section{Variabel Dependen}

Menurut Sugiyono (2016) definisi variabel dependen atau variabel terikat adalah "variabel yang dipengaruhi atau yang menjadi akibat, karena adanya variabel bebas." Variabel dependen dalam penelitian ini adalah Persepsi Mahasiswa Akuntansi Mengenai Praktik Creative Accouting. Persepsi Mahasiswa Akuntansi Mengenai Praktik Creative Accouting adalah Proses seseorang berpikir dan memberikan suatu rangsangan sesuai dengan situasi dan keadaan yang melingkupinya (Maria Yolanda, 2017) mengenai praktik creative accounting.

\section{Variabel Independen}

Menurut Sugiyono mendefinisikan variabel independen atau variabel bebas sebagai berikut: "Variabel bebas merupakan variabel yang mempengaruhi atau yang menjadi sebab perubahannya atau timbulnya variabel dependen (terikat)".

Dalam penelitian ini terdapat empat variabel bebas (independen) yang diteliti, diantaranya :

1. Pengetahuan etika

Pengetahuan adalah segala sesuatu yang diketahui kepandaian atau segala informasi yang diketahui berkenaan dengan sesuatu hal (KBBI).

Etika profesi akuntan di Indonesia diatur dalam kode etik akuntan Indonesia. Tujuan kode etik akuntan ini adalah untuk memenuhi tanggung jawab kepada pemakai jasa. Etika profesi akuntansi ini berisi tentang pedoman dasar penyusunan aturan etika yang disusun dan disahkan oleh Ikatan Akuntan Indonesia (IAI) (Aprin,2018).

2. Religiusitas

Religiusitas adalah pengabdian terhadap agama (KBBI) dan merupakan suatu keadaan yang ada dalam diri seseorang yang mendorongnya untuk bertingkah laku sesuai dengan kadar ketaatannya terhadap agama (Jalaluddin, 2001).

3. Sensitivitas etis
Sensitivitas Etis adalah kemampuan individu untuk menyadari adanya nilainilai etika dalam sebuah keputusan (Valasque dan Rostankowski, 1985; Kartika, 2013).

4. Orientasi etis

Orientasi etis merupakan suatu alternatif perilaku seseorang untuk menyelesaikan dilema etika dan konsekuensi yang diharapkan oleh fungsi yang berbeda. Perilaku etis seseorang ditentukan oleh konsep diri pada masing-masing individu sesuai dengan peran yang disandangnya (Khomsiyah dan Indriantoro, 1998).

Tabel 1

Operasionalisasi Variabel

\begin{tabular}{|c|c|c|c|c|}
\hline Variabel & $\begin{array}{l}\text { Definisi } \\
\text { Variabel }\end{array}$ & Indikator & \begin{tabular}{|c|} 
No. \\
Butir \\
Pernyat \\
aan
\end{tabular} & Skala \\
\hline $\begin{array}{l}\text { Pengetah } \\
\text { uan Etika } \\
\left(X_{1}\right)\end{array}$ & $\begin{array}{l}\text { Pengetah } \\
\text { uan } \\
\text { adalah } \\
\text { segala } \\
\text { sesuatu } \\
\text { yang } \\
\text { diketahui; } \\
\text { kepandaia } \\
\text { n; atau } \\
\text { segala } \\
\text { informasi } \\
\text { yang } \\
\text { diketahui } \\
\text { berkenaa } \\
\text { n dengan } \\
\text { sesuatu } \\
\text { hal } \\
\text { (KBBI). } \\
\text { Etika } \\
\text { Adalah } \\
\text { ilmu } \\
\text { tentang } \\
\text { apa yang( } \\
\text { baik dan } \\
\text { apa yang( } \\
\text { buruk dan } \\
\text { tentang } \\
\text { hak dan } \\
\text { kewajiban } \\
\text { moral } \\
\text { (akhlak) } \\
\text { (KBBI) } \\
\text { Etika } \\
\text { profesi } \\
\text { akuntan di } \\
\text { Indonesia } \\
\text { diatur } \\
\text { dalam } \\
\text { kode etik } \\
\text { akuntan } \\
\text { Indonesia. } \\
\text { Tujuan } \\
\text { kode etik } \\
\text { akuntan } \\
\text { ini adalah } \\
\text { untuk } \\
\text { memenuhi }\end{array}$ & \begin{tabular}{|ll} 
1. & Tanggu \\
& ng \\
& Jawab \\
2. & Profesi \\
& Kepenti \\
& ngan \\
& Publik \\
3. & Integrita \\
& s \\
4. & Objektiv \\
& itas \\
5. & Kompet \\
ensi dan \\
Kehati- \\
hatian \\
6. \\
Kerahas \\
iaan \\
7. Perilaku \\
Profesio \\
nal \\
8. Standar \\
Teknis \\
(Sukrisno dan \\
Ardana \\
$(2009:$ 162)
\end{tabular} & $\begin{array}{l}1,15^{\star} \\
2,3^{\star} \\
4,6^{\star} \\
5^{*}, 8 \\
7,11^{*} \\
9,10^{*} \\
12,16^{\star} \\
13,14^{*} \\
\end{array}$ & \begin{tabular}{|c|} 
Likert \\
STS \\
$=$ \\
San \\
gat \\
Tida \\
k \\
Set \\
uju \\
TS \\
$=$ \\
Tida \\
k \\
Set \\
uju \\
S = \\
Set \\
uju \\
SS \\
$=$ \\
San \\
gat \\
Set \\
uju
\end{tabular} \\
\hline
\end{tabular}




\begin{tabular}{|c|c|c|c|c|}
\hline & $\begin{array}{l}\text { tanggung } \\
\text { jawab } \\
\text { kepada } \\
\text { pemakai } \\
\text { jasa. Etika } \\
\text { profesi } \\
\text { akuntansi } \\
\text { ini berisi } \\
\text { tentang } \\
\text { pedoman } \\
\text { dasar } \\
\text { penyusun } \\
\text { an aturan } \\
\text { etika yang } \\
\text { disusun } \\
\text { dan } \\
\text { disahkan } \\
\text { oleh } \\
\text { lkatan } \\
\text { Akuntan } \\
\text { Indonesia } \\
\text { (IAI) } \\
\text { (Aprin,201 } \\
\text { 8). }\end{array}$ & & & \\
\hline \begin{tabular}{|l} 
Religiusita \\
s ( $\left.\mathrm{X}_{2}\right)$ \\
\\
\end{tabular} & \begin{tabular}{|l|} 
Religiusitas \\
adalah \\
pengabdian \\
terhadap \\
agama (KBBI) \\
dan \\
merupakan \\
suatu keadaan \\
yang ada \\
dalam dirik \\
seseorang \\
yang \\
mendorongnya \\
untuk \\
bertingkah laku \\
sesuai dengan \\
kadar \\
ketaatannya \\
terhadap \\
agama \\
(Jalaluddin \\
,2001)
\end{tabular} & \begin{tabular}{ll|} 
1. & $\begin{array}{l}\text { Dimensi } \\
\text { Keyakina } \\
n \\
\text { 2. }\end{array}$ \\
Dimensi \\
Peribada \\
tan \\
3. & Dimensi \\
& Pengala \\
man \\
4. & Dimensi \\
& Pengeta \\
huan \\
5. & Dimensi \\
& Konseku \\
ensi \\
(Glock dan \\
Stark,1965)
\end{tabular} & $\begin{array}{l}1,2 \\
3,4 \\
5,6 \\
7,8 \\
9,10\end{array}$ & \begin{tabular}{|c|c|} 
Likert \\
STS \\
$=$ \\
San \\
gat \\
Tida \\
k \\
Set \\
uju \\
TS \\
$=$ \\
Tida \\
k \\
Set \\
uju \\
S = \\
Set \\
uju \\
SS \\
$=$ \\
San \\
gat \\
Set \\
uju
\end{tabular} \\
\hline $\begin{array}{l}\text { Sensitivita } \\
s \text { Etis }\left(X_{3}\right)\end{array}$ & \begin{tabular}{|l|} 
Sensitivitas \\
Etis \\
Kemampuan \\
individu untuk \\
menyadari \\
adanya nilai- \\
nilai ral etika \\
dalam sebuah \\
keputusan \\
(Valasque dan \\
Rostankowski, \\
1985; \\
2013)
\end{tabular} & $\begin{array}{ll}\text { 1. } & \text { Kecuran } \\
\text { gan } \\
\text { Pada } \\
\text { Perpajak } \\
\text { an } \\
\text { Pelapora } \\
\text { n } \\
\text { Pelangg } \\
\text { aran } \\
\text { 3. Skenario } \\
\text { Bermotif } \\
\text { Laba } \\
\text { Strategi } \\
\text { Pemasar } \\
\text { an dan } \\
\text { Promosi } \\
\text { Jabatan } \\
\text { Penolaka } \\
\text { n Hak } \\
\text { Stakehol } \\
\text { der } \\
\text { (Longenecker } \\
\text { et al ,1989) }\end{array}$ & $\begin{array}{l}1,2 \\
3,4 \\
7,6 \\
9,10 \\
\end{array}$ & \begin{tabular}{|cc} 
Likert \\
$-\quad$ & STS \\
$=$ \\
San \\
gat \\
Tida \\
k \\
Set \\
uju \\
TS \\
$=$ \\
Tida \\
k \\
Set \\
uju \\
S = \\
Set \\
uju \\
SS \\
$=$ \\
San \\
gat \\
Set \\
uiu
\end{tabular} \\
\hline
\end{tabular}

\begin{tabular}{|c|c|c|c|c|}
\hline \begin{tabular}{|l} 
Orientasi \\
Etis $\left(\mathrm{X}_{4}\right)$ \\
\\
\end{tabular} & $\begin{array}{l}\text { Orientasi etis } \\
\text { merupakan } \\
\text { suatu alternatif } \\
\text { perilaku } \\
\text { seseorang } \\
\text { untuk } \\
\text { menyelesaikan } \\
\text { dilema etika } \\
\text { dan } \\
\text { konsekuensi } \\
\text { yang } \\
\text { diharapkan } \\
\text { oleh fungsi } \\
\text { yang berbeda. } \\
\text { Perilaku etis } \\
\text { seseorang } \\
\text { ditentukan oleh } \\
\text { konsep diri } \\
\text { pada masing- } \\
\text { masing } \\
\text { individu sesuai } \\
\text { dengan peran } \\
\text { yang } \\
\text { disandangnya } \\
\text { (Khomsiyah } \\
\text { dan } \\
\text { Indriantoro, } \\
\text { 1998). }\end{array}$ & $\begin{array}{ll}\text { 1. } & \text { Idealism } \\
\text { e } \\
\text { 2. } & \text { Relativis } \\
\text { me } \\
\text { Greenfield } \\
\text { t.al,2007) }\end{array}$ & \begin{tabular}{|l|}
$1,2,3,4$, \\
$5,6,7,8$, \\
9,10 \\
11,12, \\
13,14, \\
15,16, \\
17,18, \\
19,20
\end{tabular} & \begin{tabular}{|c|} 
Likert \\
STS \\
$=$ \\
San \\
gat \\
Tida \\
k \\
Set \\
uju \\
TS \\
$=$ \\
Tida \\
k \\
Set \\
uju \\
S = \\
Set \\
uju \\
SS \\
$=$ \\
San \\
gat \\
Set \\
uju
\end{tabular} \\
\hline \begin{tabular}{|l|} 
Persepsi \\
Mengenai \\
Praktik \\
Creative \\
accountin \\
$g(\mathrm{Y})$
\end{tabular} & $\begin{array}{l}\text { Persepsi } \\
\text { adalah } \\
\text { pengalam } \\
\text { an } \\
\text { tentang } \\
\text { obyek, } \\
\text { peristiwa, } \\
\text { atau } \\
\text { hubungan } \\
\text { - } \\
\text { hubungan } \\
\text { yang } \\
\text { diperoleh } \\
\text { dengan } \\
\text { menyimpu( } \\
\text { lkan } \\
\text { informasi } \\
\text { dan } \\
\text { menafsirk } \\
\text { an pesan } \\
\text { (Henry, } \\
\text { 2013). } \\
\text { Creative } \\
\text { accountin } \\
\text { g } \\
\text { merupaka } \\
\text { n suatu } \\
\text { usaha } \\
\text { organisasi } \\
\text { atau } \\
\text { badan } \\
\text { usaha } \\
\text { untuk } \\
\text { memanfa } \\
\text { atkan } \\
\text { teknik dan } \\
\text { kebijakan } \\
\text { akuntansi } \\
\text { yang } \\
\text { bertujuan } \\
\text { untuk } \\
\text { mendapat } \\
\text { kan hasil } \\
\text { laporan } \\
\text { keuanngan } \\
\text { yang } \\
\text { diinginkan }\end{array}$ & 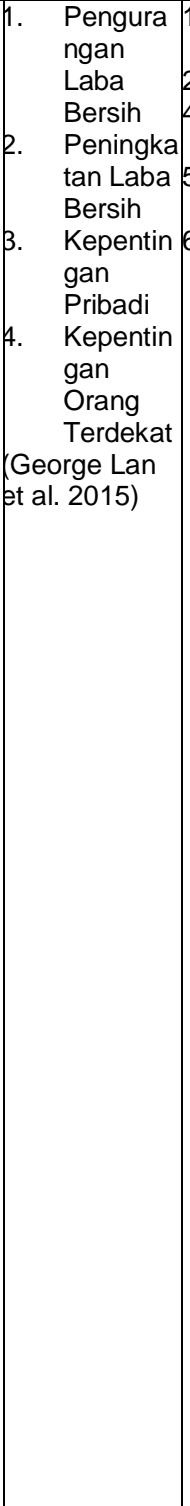 & $\mid \begin{array}{l}1 \\
2,3 a, 3 b \\
4,8 \\
6,7 \\
5\end{array}$ & \begin{tabular}{|c|} 
Likert \\
STS \\
$=$ \\
San \\
gat \\
Tida \\
k \\
Set \\
uju \\
TS \\
$=$ \\
Tida \\
$k$ \\
Set \\
uju \\
S = \\
Set \\
uju \\
SS \\
$=$ \\
San \\
gat \\
Set \\
uju
\end{tabular} \\
\hline
\end{tabular}




\begin{tabular}{|l|l|l|l|l|}
\hline & $\begin{array}{l}\text { (Sulistiaw } \\
\text { an, } \\
\text { 2006). }\end{array}$ & & & \\
\hline
\end{tabular}

\section{Uji Kualitas Data}

\section{Uji Validitas}

Uji validitas digunakan untuk mengukur sejauh mana sebuah pertanyaan pada kuesioner mampu menjawab suatu hal yang akan diukur dalam kuesioner tersebut, dan memastikan bahwa setiap pertanyaan dalam kuesioner akan terklarifikasi pada variabel yang sudah ditetapkan. Apabila sebuah pertanyaan mampu menjawab suatu hal yang akan diukur dalam kuesioner tersebut, maka pertanyaan tersebut adalah valid.

\section{Uji Reliabilitas}

Menurut Ghozali (2013): "uji reliabilitas adalah alat untuk mengukur suatu kuesioner yang merupakan indikator dari variabel atau konstruk". Suatu kuesioner dikatakan reliabel atau handal jika jawaban seseorang terhadap pernyataan adalah konsisten atau stabil dari waktu ke waktu.

\section{Uji Asumsi Klasik}

\section{Uji Normalitas}

Menurut Ghozali (2013) : “Uji normalitas bertujuan untuk menguji apakah dalam model regresi, variabel pengganggu atau residual memiliki distribusi normal". Pada prinsipnya normalitas dapat dideteksi dengan melihat penyebaran data (titik) pada sumbu diagonal dari grafik atau dengan melihat histogram dari residualnya. Dasar pengambilan keputusan dibagi menjadi dua, yaitu (Ghozali, 2013):

1. Jika data menyebar disekitar garis diagonal dan mengikuti arah garis diagonal atau grafik histogramnya menunjukkan pola distribusi normal, maka model regresi memenuhi asumsi normalitas.

2. Jika data menyebar jauh dari diagonal dan atau tidak mengikuti arah garis diagonal atau grafik histogram tidak menunjukkan pola distribusi normal, maka model regresi tidak memenuhi asumsi normalitas.

\section{Uji Heteroskedastisitas}

Menurut Ghozali (2013) menyatakan: “Uji heteroskedastisitas bertujuan menguji apakah dalam model regresi terjadi ketidaksamaan varian dari residual satu pengamatan yang lain". Jika variance dari residual satu pengamatan lain tetap, maka disebut homokedastisitas, dan jika berbeda disebut heteroskedastisitas. Model regresi yang baik adalah yang homokedastisitas atau tidak terjadi heteroskedastisitas. Dalam mendeteksi ada atau tidaknya heteroskedastisitas dapat menggunakan uji glejser, dimana profitabilitas signifikan dari variabel independen harus diatas tingkat kepercayaan 5\% atau 0,05 maka dapat dinyatakan tidak terjadi heteroskedastisitas (Ghozali, 2013).

\section{Uji Multikolinearitas}

Menurut Ghozali (2013) menyatakan bahwa "Uji multikolinearitas bertujuan untuk menguji apakah model regresi ditemukan adanya korelasi antar variabel bebas (independen)". Model regresi yang baik seharusnya tidak terjadi korelasi antara variabel independen.

Dasar pengambilan keputusan uji multikolinearitas adalah sebagai:

1. Mempunyai variance inflation factor $(\mathrm{VIF})<10,00$.

2. Mempunyai angka tolerance $>0,10$.

\section{Uji Hipotesis}

\section{Analisis Regresi Berganda}

Menurut Ghozali (2013): "Analisis regresi digunakan untuk mengukur kekuatan hubungan antara dua variabel atau lebih, juga menunjukkan arah hubungan antara variabel dependen dengan independen". Analisis regresi linear berganda adalah hubungan secara linear antara dua atau lebih veriabel independen (X) dengan variabel dependen ( $\mathrm{Y}$ ). Analisis ini untuk memprediksi nilai dari variabel independen mengalami kenaikan atau penurunan dan untuk mengetahu arah hubungan antara variabel independen dengan variabel dependen apakah masingmasing variabel independen berhubungan positif atau negatif. Perhitungan regresi linear berganda dihitung sebagai berikut:

$$
Y=a+\beta_{1} X_{1}+\beta_{2} X_{2}+\beta_{3} X_{3}+\beta_{4} X_{3}+e
$$

Keterangan: 
$\mathrm{Y}=$ Persepsi Mahasiswa Akuntansi Mengenai Praktik Creative Accounting

$\mathrm{a}=$ Konstanta

$\beta_{1} \ldots \beta_{4}=$ Koefisien Regresi

$X_{1} \quad=$ Pengetahuan Etika

$\mathrm{X}_{2}=$ Religiusitas

$\mathrm{X}_{3}=$ Sensitivitas Etis

$\mathrm{X}_{4} \quad=$ Orientasi Etis

e $\quad=$ Error

\section{Uji Statistik t (Parsial)}

Menurut Ghozali

(2013:98) menjelaskan bahwa: "uji statistik $\mathrm{t}$ pada dasarnya menunjukkan sebarapa jauh pengaruh satu variabel penjelas (independen) secara individual dalam menerangkan variabel-variabel dependen." Hipotesis nol (Ho) yang hendak diuji adalah apakah suatu parameter (bi) sama dengan nol, atau:

$$
\text { Ho : bi = } 0
$$

Artinya, apakah suatu variabel independen bukan merupakan penjelas yang signifikan terhadap variabel dependen. Hipotesis alternatifnya $\left(\mathrm{H}_{\mathrm{a}}\right)$ parameter suatu variabel tidak sama dengan nol, atau:

$$
\text { Ho : bi } \neq 0
$$

Artinya, variabel tersebut merupakan penjelas yang signifikan terhadap variabel dependen. Cara melakukan uji t adalah sebagai berikut (Ghozali,2013:99):

1. Quick look : bila jumlah target degree of freedom (df) adalah 20 atau lebih dan derajat kepercayaan sebesar $5 \%$, maka $\mathrm{Ho}$ yang menyatakan $\mathrm{bi}=0$ dapat ditolak bila nilai $\mathrm{t}$ lebih besar dari 2 (dalam nilai absolut). Dengan kata lain, kita menerima hipotesis alternatif, yang menyatakan bahwa suatu variabel independen secara individual mempengaruhi variabel dependen.

2. Membandingkan nilai statistik t dengan titik kritis menurut tabel. Apabila nilai statistik t hasil perhitungan lebih tinggi dibandingkan nilai $t$ tabel, kita menerima hipotesis alternatif yang menyatakan bahwa suatu variabel independen secara individual mempengaruhi variabel dependen.

\section{Uji Statistik F (Simultan)}

Menurut Ghozali (2013) menjelaskan bahwa: "Uji statistik $F$ pada dasarnya menunjukkan apakah semua variabel independen atau bebas yang dimasukkan dalam model mempunyai pengaruh secara bersama-sama terhadap variabel dependen (terikat)." Hipotesis nol (Ho) yang hendak diuji adalah apakah semua parameter dalam model sama dengan nol, atau:

$$
\mathrm{H}_{0}: \mathrm{b} 1=\mathrm{b} 2=\ldots \ldots=\mathrm{bk}=0
$$

Artinya, apakah semua variabel independen bukan merupakan penjelas yang signifikan terhadap variabel dependen. Hipotesis alternatifnya $\left(\mathrm{H}_{\mathrm{a}}\right)$ tidak semua parameter secara simultan sama dengan nol atau:

$$
\mathrm{H}_{\mathrm{a}}: \mathrm{b} 1 \neq \mathrm{b} 2 \neq \ldots \ldots \neq \mathrm{bk} \neq 0
$$

Artinya, semua variabel independen secara simultan merupakan penjelas yang signifikan terhadap variabel dependen. Kriteria pengambilan keputusan yaitu bila nilai $F_{\text {hitung }}>\mathrm{F}_{\text {tabel }}$ maka $\mathrm{H}_{0}$ dapat ditolak pada derajat kepercayaan $5 \%$. Dengan kata lain, kita menerima hipotesis alternatif yang menyatakan bahwa semua variabel independen secara serentak dan signifikan mempengaruhi variabel dependen (Ghozali, 2013).

\section{Koefisien Determinasi $\left(\mathbf{R}^{2}\right)$}

Menurut Ghozali (2013) menjelaskan bahwa: "Koefisien determinasi $\left(R^{2}\right)$ pada intinya mengukur seberapa jauh kemampuan model dalam menerangkan variasi variabel dependen". Nilai koefisien determinasi adalah antara nol dan satu. Nilai $R^{2}$ yang kecil berarti kemampuan variabel-variabel independen dalam menjelaskan variasi variabel dependen amat terbatas. Secara sistematis jika:

$$
R^{2}=1 \text {, maka Adjusted } R^{2}=R^{2}=1 \text {. }
$$

Sedangkan jika nilai $R^{2}=0$, maka Adjusted

$R^{2}=(1-k)(n-k)$. Jika $k>1$, maka Adjusted $R^{2}$ akan bernilai negatif.

\section{HASIL DAN PEMBAHASAN}

\section{Deskriptif Data Penelitian}

Jumlah kuesioner yang disebar adalah sebanyak 329 kuesioner dan jumlah kuesioner yang kembali sebanyak 324 kuesioner. Hanya 320 kuesioner yang dapat diolah karena terdapat 4 data kuesioner outlier atau data ekstrem yang tidak dapat diolah. Data yang diperoleh, selanjutnya dianalisis sesuai dengan kebutuhan 
peneliti. Berikut ini rincian penyebaran kuesioner penelitian:

Tabel 2

Rincian Penyebaran Kuesioner

\begin{tabular}{|c|c|c|}
\hline Keterangan & Jumlah & Presentase \\
\hline $\begin{array}{c}\text { Total kuesioner } \\
\text { yang disebar }\end{array}$ & 329 & $100 \%$ \\
\hline $\begin{array}{c}\text { Total kuesioner } \\
\text { yang kembali }\end{array}$ & 324 & $99,02 \%$ \\
\hline $\begin{array}{c}\text { Total kuesioner } \\
\text { yang tidak dapat } \\
\text { diolah }\end{array}$ & $(4)$ & $1,23 \%$ \\
\hline $\begin{array}{c}\text { Total kuesioner } \\
\text { yang dapat } \\
\text { diolah dalam } \\
\text { penelitian }\end{array}$ & 320 & $97,79 \%$ \\
\hline
\end{tabular}

Sumber: Data diolah, 2021

\section{Deskriptif Data Responden}

\section{Jenis Kelamin}

Data mengenai jenis kelamin responden dikelompokkan menjadi dua yaitu laki-laki dan perempuan. Berdasarkan data penelitian yang dilakukan melalui penyebaran kuesioner secara online, penelitian ini melibatkan responden laki-laki sebanyak 92 orang atau 29\%, sedangkan perempuan sebanyak 228 orang atau $71 \%$. Berikut ini grafik data jenis kelamin responden yang dijelaskan pada gambar 2:

\section{JENIS KELAMIN}

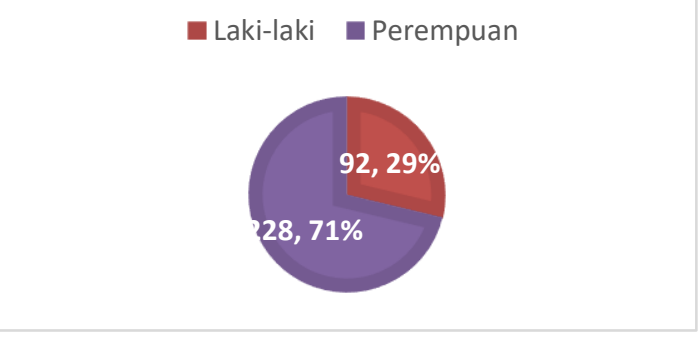

\section{Gambar 2 \\ Karakteristik Responden Berdasarkan Jenis Kelamin \\ Sumber : Data Diolah, 2021}

\section{Perguruan Tinggi}

Data mengenai perguruan tinggi responden dikelompokan menjadi dua yaitu negeri dan swasta. Berdasarkan data penelitian yang dilakukan melalui penyebaran kuesioner secara online, penelitian ini melibatkan responden yang berkuliah diperguruan tinggi negeri sebanyak 91 orang atau $28 \%$, sedangkan responden yang berkuliah diperguruan tinggi swasta sebanyak 229 orang atau $72 \%$. Berikut ini grafik data perguruan tinggi responden yang dijelaskan pada gambar 3 :

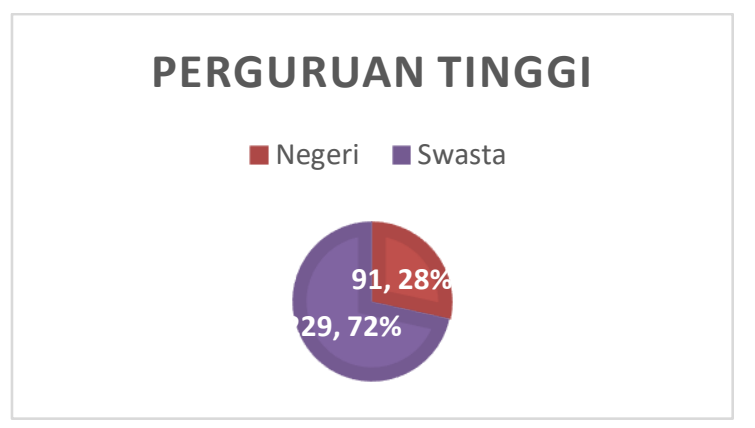

Gambar 3

Karakteristik Responden Berdasarkan Perguruan Tinggi

Sumber : Data Diolah, 2021

\section{Kota Perguruan Tinggi}

Tabel 3

Karakteristik Responden Berdasarkan Kota Perguruan Tinggi

\begin{tabular}{|c|c|c|c|}
\hline No. & Kota & Jumlah & Persentase \\
\hline 1 & Subang & 77 & $24,1 \%$ \\
\hline 2 & Bandung & 123 & $38,4 \%$ \\
\hline 3 & Purwakarta & 5 & $1,6 \%$ \\
\hline 4 & Cirebon & 20 & $6,3 \%$ \\
\hline 5 & Karawang & 23 & $7,2 \%$ \\
\hline 6 & Depok & 3 & $0,9 \%$ \\
\hline 7 & Sumedang & 6 & $1,9 \%$ \\
\hline 8 & Garut & 7 & $2,2 \%$ \\
\hline 9 & Bekasi & 7 & $2,2 \%$ \\
\hline 10 & Cimahi & 17 & $5,3 \%$ \\
\hline 11 & Tasikmalaya & 13 & $4,1 \%$ \\
\hline 12 & Kuningan & 1 & $0,3 \%$ \\
\hline 13 & Ciamis & 3 & $0,9 \%$ \\
\hline 14 & Bogor & 9 & $2,8 \%$ \\
\hline 15 & Cianjur & 2 & $0,6 \%$ \\
\hline 16 & Majalengka & 2 & $0,6 \%$ \\
\hline 17 & Sukabumi & 2 & $0,6 \%$ \\
\hline \multicolumn{2}{|r|}{ Total } & 320 & $100 \%$ \\
\hline
\end{tabular}

Mata Kuliah Yang Sudah Atau Sedang Ditempuh 
Tabel 4

Karakteristik Responden Berdasarkan Mata Kuliah Yang Sudah atau Sedang Ditempuh

\begin{tabular}{|l|c|c|}
\hline Mata Kuliah & Jumlah & Persentase \\
\hline $\begin{array}{l}\text { Etika Bisnis } \\
\text { dan Profesi } \\
\text { (atau yang } \\
\text { sejenisnya), } \\
\text { Akuntansi } \\
\text { Keuangan, } \\
\text { Pengauditan }\end{array}$ & 166 & $51,9 \%$ \\
\hline $\begin{array}{l}\text { Etika Bisnis } \\
\text { dan Profesi } \\
\text { (atau yang } \\
\text { sejenisnya), } \\
\text { Akuntansi } \\
\text { Keuangan }\end{array}$ & 59 & $18,4 \%$ \\
\hline $\begin{array}{l}\text { Akuntansi } \\
\text { Keuangan, } \\
\text { Pengauditan }\end{array}$ & 85 & $26,6 \%$ \\
\hline $\begin{array}{l}\text { Etika Bisnis } \\
\text { dan Profesi } \\
\text { (atau yang } \\
\text { sejenisnya), } \\
\text { Pengauditan }\end{array}$ & 10 & $3,1 \%$ \\
\hline \multicolumn{1}{|c|}{ Total } & $\mathbf{3 2 0}$ & $\mathbf{1 0 0 \%}$ \\
\hline
\end{tabular}

Sumber: Data diolah, 2021

\section{Semester}

Tabel 5

Karakteristik Responden Berdasarkan Semester

\begin{tabular}{|c|l|c|c|}
\hline No. & Keterangan & Jumlah & Persentase \\
\hline 1 & Semester 3 & 7 & $2,2 \%$ \\
\hline 2 & Semester 4 & 65 & $20,3 \%$ \\
\hline 3 & semester 5 & 8 & $2,5 \%$ \\
\hline 4 & Semester 6 & 151 & $47,2 \%$ \\
\hline 5 & Semester 7 & 9 & $2,8 \%$ \\
\hline 6 & Semester 8 & 80 & $25 \%$ \\
\hline \multicolumn{2}{|l}{ Total } & $\mathbf{3 2 0}$ & $\mathbf{1 0 0 \%}$ \\
\hline
\end{tabular}

Sumber: Data diolah, 2021

\section{Analisis Deskriptif Variabel}

\section{Deskriptif Variabel Pengetahuan Etika}

Tabel 6

Kategori Kecenderungan Variabel Pengetahuan Etika

\begin{tabular}{|c|c|c|c|c|}
\hline No. & $\begin{array}{c}\text { Kelas } \\
\text { Interv } \\
\text { al }\end{array}$ & $\begin{array}{c}\text { Frekuen } \\
\text { si }\end{array}$ & $\begin{array}{c}\text { Presenta } \\
\text { se }\end{array}$ & $\begin{array}{c}\text { Katego } \\
\text { ri }\end{array}$ \\
\hline 1 & $>39$ & 239 & $74,7 \%$ & Tinggi \\
\hline 2 & $\begin{array}{c}26 \mathrm{~s} / \mathrm{d} \\
39\end{array}$ & 81 & $25,3 \%$ & Sedang \\
\hline 3 & $<26$ & 0 & 0 & Rendah \\
\hline
\end{tabular}

\begin{tabular}{|c|c|c|c|}
\hline Total & $\mathbf{3 2 0}$ & $\mathbf{1 0 0 \%}$ & \\
& & & \\
\hline \multicolumn{2}{l}{ Sumber: Data diolah, 2021} \\
\end{tabular}

Dari tabel 6 di atas menunjukkan bahwa tingkat pengetahuan etika mahasiswa akuntansi pada kategori tinggi sebanyak 239 mahasiswa (74,7\%), dan hanya 81 mahasiswa $(25,3 \%)$ yang memiliki tingkat pengetahuan etika sedang. Pada kategori rendah, terbukti bahwa tidak adanya mahasiswa yang memiliki tingkat pengetahuan etika rendah. Hal ini berarti bahwa mahasiswa akuntansi perguruan tinggi di Jawa Barat memiliki tingkat pengetahuan mengenai kode etik akuntan yang tinggi.

\section{Deskriptif Variabel Religiusitas}

Tabel 7

Kategori Kecenderungan Variabel Religiusitas

\begin{tabular}{|c|c|c|c|c|}
\hline No. & $\begin{array}{c}\text { Kelas } \\
\text { Interval }\end{array}$ & $\begin{array}{c}\text { Frekue } \\
\text { nsi }\end{array}$ & $\begin{array}{c}\text { Presen } \\
\text { tase }\end{array}$ & $\begin{array}{c}\text { Katego } \\
\text { ri }\end{array}$ \\
\hline 1 & $>27$ & 288 & $90 \%$ & Tinggi \\
\hline 2 & $18 \mathrm{~s} / \mathrm{d} 27$ & 32 & $10 \%$ & Sedang \\
\hline 3 & $<18$ & 0 & $0 \%$ & Rendah \\
\hline \multicolumn{2}{|c|}{ Total } & $\mathbf{3 2 0}$ & $\mathbf{1 0 0} \%$ & \\
\hline
\end{tabular}

Sumber: Data diolah, 2021

Dari tabel 7 di atas menunjukkan bahwa tingkat religiusitas mahasiswa akuntansi pada kategori tinggi sebanyak 288 mahasiswa (90\%), pada kategori Religiusitas sedang sebanyak 32 mahasiswa (10\%) dan ada kategori rendah, terbukti bahwa tidak adanya mahasiswa yang memiliki tingkat religiusitas yang rendah. Hal ini berarti bahwa mahasiswa akuntansi perguruan tinggi di Jawa Barat memiliki tingkat keberagamaan yang tinggi.

\section{Deskriptif Variabel Sensitivitas Etis}

Tabel 8

Kategori Kecenderungan Variabel Sensitivitas Etis

\begin{tabular}{|c|c|c|c|c|}
\hline No. & $\begin{array}{c}\text { Kelas } \\
\text { Interva } \\
\text { I }\end{array}$ & $\begin{array}{c}\text { Frekue } \\
\text { nsi }\end{array}$ & $\begin{array}{c}\text { Presen } \\
\text { tase }\end{array}$ & $\begin{array}{c}\text { Katego } \\
\text { ri }\end{array}$ \\
\hline 1 & $>30$ & 180 & $56,3 \%$ & Tinggi \\
\hline 2 & $\begin{array}{c}20 \mathrm{~s} / \mathrm{d} \\
30\end{array}$ & 126 & $39,4 \%$ & Sedang \\
\hline
\end{tabular}




\begin{tabular}{|c|c|c|c|c|}
\hline 3 & $<20$ & 14 & $4,4 \%$ & Rendah \\
\hline \multicolumn{2}{|c|}{ Total } & $\mathbf{3 2 0}$ & $\mathbf{1 0 0 \%}$ & \\
\hline
\end{tabular}

Sumber: Data diolah, 2021

Dari tabel 8 di atas menunjukkan bahwa tingkat sensitivitas etis mahasiswa akuntansi pada kategori tinggi sebanyak 180 mahasiswa (56,3\%), sedangkan mahasiswa yang memiliki tingkat sensitivitas etis sedang sebanyak 126 mahasiswa $(39,4 \%)$ dan pada kategori rendah ada sebanyak 14 mahasiswa $(4,4 \%)$. Hal ini menunjukkan bahwa mahasiswa akuntansi perguruan tinggi di Jawa Barat memiliki tingkat Sensitivitas terhadap perilaku etis yang tinggi.

\section{Deskriptif Variabel Orientasi Etis}

Tabel 9

Distribusi Frekuensi Variabel Orientasi Etis

\begin{tabular}{|c|c|c|c|}
\hline No. & $\begin{array}{c}\text { Orientasi } \\
\text { Etis }\end{array}$ & $\begin{array}{c}\text { Juml } \\
\text { ah }\end{array}$ & Presentase \\
\hline 1 & Idealisme & 139 & $43,4 \%$ \\
\hline 2 & Relativisme & 181 & $56,6 \%$ \\
\hline \multicolumn{2}{r|}{ Total } & $\mathbf{3 2 0}$ & $\mathbf{1 0 0} \%$ \\
\hline
\end{tabular}

Sumber: Data diolah, 2021

Berdasarkan hasil pengujian cluster non hierarki orientasi etis, jumlah mahasiswa idealist sebanyak 139 orang dan relativis sebanyak 181 orang. Pengkategorian berdasarkan nilai pada final cluster centers yang dinyatakan pada hasil uji cluster non hierarki terlihat koefisien nilai Zscore I dan Zscore R negatif pada cluster 1 dan positif pada cluster 2. Sehingga dapat dinyatakan bahwa cluster 1 adalah mahasiswa yang idealist dan cluster 2 adalah mahasiswa yang relativis.

Deskriptif Variabel Persepsi Mahasiswa Akuntansi Mengenai Praktik Creative Accounting

Tabel 10

Kategori Kecenderungan Variabel Persepsi Mahasiswa Akuntansi Mengenai Praktik Creative Accounting

\begin{tabular}{|c|c|c|c|c|}
\hline No. & $\begin{array}{c}\text { Kelas } \\
\text { Interval }\end{array}$ & $\begin{array}{c}\text { Frekue } \\
\text { nsi }\end{array}$ & $\begin{array}{c}\text { Prese } \\
\text { ntase }\end{array}$ & $\begin{array}{c}\text { Kateg } \\
\text { ori }\end{array}$ \\
\hline
\end{tabular}

\begin{tabular}{|c|c|c|c|c|}
\hline 1 & $>27$ & 29 & $9,1 \%$ & $\begin{array}{c}\text { Sangat } \\
\text { Etis }\end{array}$ \\
\hline 2 & 18 s/d 27 & 273 & $85,3 \%$ & Etis \\
\hline 3 & $<18$ & 18 & $5,6 \%$ & $\begin{array}{c}\text { Tidak } \\
\text { Etis }\end{array}$ \\
\hline \multicolumn{2}{|c|}{ Total } & $\mathbf{3 2 0}$ & $\mathbf{1 0 0} \%$ & \\
\hline
\end{tabular}

Sumber: Data diolah, 2021

Dari tabel 10 di atas menunjukkan bahwa frekuensi persepsi mahasiswa akuntansi mengenai praktik creative accounting pada kategori sangat etis sebanyak 29 mahasiswa $(9,1 \%)$, sedangkan pada kategori etis sebanyak 273 mahasiswa $(85,3 \%)$, dan mahasiswa pada kategori tidak etis sebanyak 18 mahasiswa $(5,6 \%)$. Hal ini berarti bahwa mahasiswa akuntansi perguruan tinggi di Jawa Barat dalam situasi terjadinya praktik creative accounting, kecenderungan mahasiswa yang berpersepsi etis jauh lebih tinggi dari pada mahasiswa yang tidak berpersepsi etis.

\section{Uji Asumsi Klasik}

\section{Uji Normalitas}

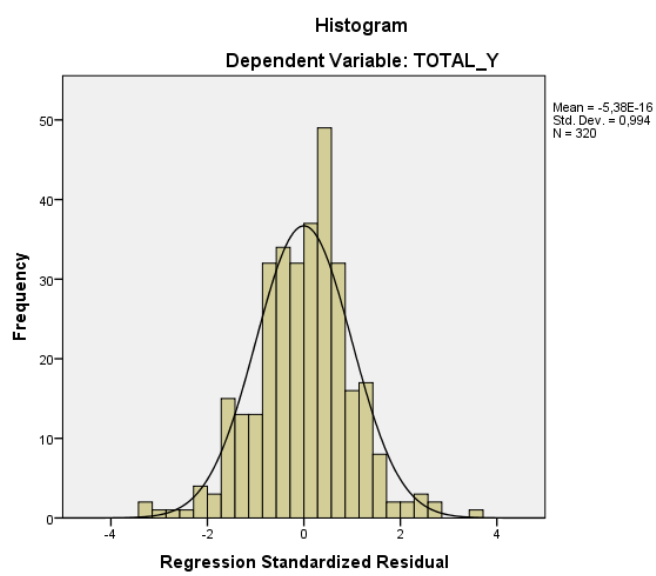

Gambar 4

Hasil Uji Normalitas dengan Analisis Histogram Sumber: Output SPSS Versi 22.0 
Normal P-P Plot of Regression Standardized Residual Dependent Variable: TOTAL_Y

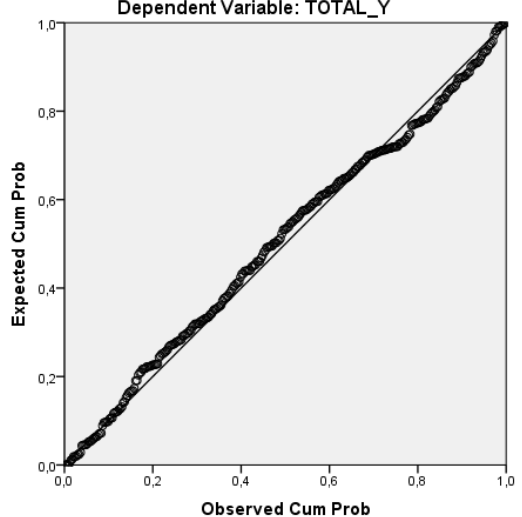

Gambar 5

Hasil Uji Normalitas dengan Analisis Grafik Plot Sumber: Output SPSS Versi 22.0

Dengan melihat tampilan grafik normalitas plot dapat disimpulkan bahwa grafik histogram memberikan pola distribusi yang normal. Sedangkan pada grafik plot terlihat titik-titik menyebar disekitar garis diagonal. Pada prinsipnya normalitas dapat dideteksi dengan melihat histogram dari residualnya. Artinya model regresi memenuhi asumsi normalitas. Untuk semakin meyakinkan hasil dari uji normalitas, maka dalam penelitian ini akan dilakukan pengujian lebih lanjut dengan menggunakan uji statistik non-parametrik Kolmogorov-Smirnov.

Tabel 11

One-Sample Kolmogorov-Smirnov Test

\begin{tabular}{|ll|r|}
\hline & & $\begin{array}{r}\text { Unstandardi } \\
\text { zed } \\
\text { Residual }\end{array}$ \\
\hline $\mathrm{N}$ & Mean & 320 \\
Normal &, 0000000 \\
Parameters $^{\mathrm{a}, \mathrm{b}}$ & Std. & 2,79718874 \\
& Deviation &, 040 \\
Most & Absolute &, 039 \\
Extreme & Positive &,- 040 \\
Differences & Negative &, 040 \\
Test Statistic & &, $200^{\mathrm{c}, \mathrm{d}}$ \\
\hline
\end{tabular}

Sumber: Output SPSS Versi 22.0

Berdasarkan tabel 11 diatas dapat dilihat bahwa nilai signifikan 0,200 >0,05. Maka sesuai dengan dasar pengambilan keputusan dalam uji normalitas Kolmogorov-Smirnov diatas, dapat disimpulkan bahwa data berdistribusi normal. Dengan demikian, asumsi atau persyaratan normalitas dalam model regresi sudah terpenuhi.

\section{Uji Multikolinearitas}

Tabel 12

Hasil Uji Multikolinearitas

Coefficients $^{a}$

\begin{tabular}{|ll|r|c|}
\hline \multirow{2}{*}{ Model } & & \multicolumn{2}{|c|}{ Collinearity Statistics } \\
\cline { 3 - 4 } & & Tolerance & \multicolumn{1}{c|}{ VIF } \\
\hline \multirow{2}{*}{1} & TOTAL_X1 &, 465 & 2,150 \\
& TOTAL_X2 &, 863 & 1,159 \\
& TOTAL_X3 &, 483 & 2,069 \\
& TOTAL_X4 &, 856 & 1,169 \\
\hline
\end{tabular}

Sumber: Output SPSS Versi 22.0

Berdasarkan tabel 12 output "Coeffcients" pada bagian "Collinearity Statistics" diketahui bahwa nilai Tolerance untuk semua variabel $>0,10$ dan nilai VIF untuk semua variabel $<10,00$. Maka mengacu pada dasar pengambilan keputusan dalam uji multikolinearitas dapat disimpulkan bahwa tidak terjadi multikolinearitas dalam model regresi.

Uji Heteroskedastisitas

Tabel 13

Hasil Uji Heteroskedastisitas dengan Uji Glejser Coefficients $^{a}$

\begin{tabular}{|ll|r|r|}
\hline \multicolumn{1}{|l|}{} & & \multicolumn{1}{c|}{$\mathrm{t}$} & \multicolumn{1}{c|}{ Sig. } \\
\hline 1 & & $-1,083$ &, 280 \\
& (Constant) &,- 245 &, 806 \\
& TOTAL_X1 & 1,407 &, 161 \\
& TOTAL_X2 & 1,064 &, 288 \\
& TOTAL_X3 & 1,920 &, 056 \\
\hline \multicolumn{2}{|r|}{ TOTAL_X4 } \\
Sumber: Output SPSS Versi 22.0
\end{tabular}

Berdasarkan tabel 13 diketahui nilai signifikansi untuk semua variabel $>0,05$, maka sesuai dengan dasar pengambilan keputusan dalam uji glejser, dapat disimpulkan bahwa tidak terjadi gejala heteroskedastisitas dalam model regresi.

\section{Uji Hipotesis}

\section{Analisis Regresi Berganda}

Tabel 14

Model Persamaan Regresi

Coefficients $^{a}$ 


\begin{tabular}{|c|c|c|c|c|c|}
\hline \multirow[b]{2}{*}{ Model } & \multicolumn{2}{|c|}{$\begin{array}{l}\text { Unstandard } \\
\text { ized } \\
\text { Coefficients }\end{array}$} & $\begin{array}{c}\text { Standar } \\
\text { dized } \\
\text { Coeffici } \\
\text { ents } \\
\end{array}$ & \multirow[b]{2}{*}{$t$} & \multirow[b]{2}{*}{ Sig. } \\
\hline & B & $\begin{array}{l}\text { Std. } \\
\text { Err } \\
\text { or }\end{array}$ & Beta & & \\
\hline (Constant) & $\begin{array}{r}12,92 \\
4\end{array}$ & $\begin{array}{r}2,2 \\
60\end{array}$ & & $\begin{array}{r}5,7 \\
17\end{array}$ & ,000 \\
\hline $\begin{array}{l}\text { TOTAL_X } \\
1\end{array}$ & , 140 & $\begin{array}{r}, 04 \\
2\end{array}$ & ,204 & $\begin{array}{r}3,3 \\
10\end{array}$ & ,001 \\
\hline $\begin{array}{l}\text { TOTAL_X } \\
2\end{array}$ &,- 071 & $\begin{array}{r}, 05 \\
3\end{array}$ &,- 060 & $\begin{array}{r}- \\
1,3 \\
22\end{array}$ & ,187 \\
\hline $\begin{array}{l}\text { TOTAL_X } \\
3\end{array}$ & 295, & $\begin{array}{r}, 03 \\
7\end{array}$ & ,483 & $\begin{array}{r}7,9 \\
84\end{array}$ & ,000 \\
\hline $\begin{array}{l}\text { TOTAL_X } \\
4\end{array}$ &,- 052 & $\begin{array}{r}, 02 \\
7\end{array}$ &,- 088 & $\begin{array}{r}- \\
1,9 \\
34\end{array}$ & ,054 \\
\hline
\end{tabular}

Berdasarkan tabel 14 di atas dapat diketahui nilai konstanta dan koefisien regresi. Sehingga berdasarkan output tersebut dapat dibuat sebuah persamaan regresi berganda sebagai berikut:

$Y=12,924+0,140 X_{1}-0,071 X_{2}+0,295 X_{3}$

$$
-0,052 X_{4}+e
$$

Model regresi tersebut dapat diinterpretasikan sebagai berikut:

1. Konstanta sebesar 12,924 menyatakan bahwa jika variabel independennya yaitu pengetahuan etika $\left(X_{1}\right)$, religiusitas $\left(X_{2}\right)$, sensitivitas etis $\left(X_{3}\right)$, dan orientasi etis $\left(X_{4}\right)$ tidak ada atau sama dengan nol maka nilai persepsi mahasiswa akuntansi mengenai praktik creative accounting sebesar 12,924.

2. Nilai koefisien regresi variabel pengetahuan etika sebesar 0,140 . Hal tersebut menyatakan bahwa jika pengetahuan etika mengalami penambahan sebesar 1 maka nilai persepsi mahasiswa akuntansi mengenai praktik creative accounting akan mengalami peningkatan sebesar 0,140 .

3. Nilai koefisien regresi variabel religiusitas sebesar $-0,071$. Hal tersebut menyatakan bahwa jika religiusitas mengalami penurunan sebesar 1 maka nilai persepsi mahasiswa akuntansi mengenai praktik creative accounting akan mengalami peningkatan sebesar $-0,071$.

4. Nilai koefisien regresi sensitivitas etis sebesar 0,295. Hal tersebut menyatakan bahwa jika sensitivitas etis mengalami peningkatan sebesar 1 maka nilai persepsi mahasiswa akuntansi mengenai praktik creative accounting akan mengalami peningkatan sebesar 0,295.

5. Nilai koefisien regresi variabel orientasi etis sebesar -0,052. Hal tersebut menyatakan bahwa jika orientasi etis mengalami penurunan sebesar 1 maka nilai persepsi mahasiswa akuntansi mengenai praktik creative accounting akan mengalami peningkatan sebesar 0,052 .

\section{Uji Statistik t (Parsial)}

Tabel 15

Hasil Uji Statistik t (Parsial)

Coefficients $^{a}$

\begin{tabular}{|c|c|c|c|c|c|}
\hline \multirow[b]{2}{*}{ Model } & \multicolumn{2}{|c|}{$\begin{array}{l}\text { Unstandard } \\
\text { ized } \\
\text { Coefficients }\end{array}$} & $\begin{array}{c}\text { Standar } \\
\text { dized } \\
\text { Coeffici } \\
\text { ents } \\
\end{array}$ & \multirow[b]{2}{*}{$\mathrm{t}$} & \multirow[b]{2}{*}{ Sig. } \\
\hline & B & $\begin{array}{l}\text { Std. } \\
\text { Err } \\
\text { or }\end{array}$ & Beta & & \\
\hline (Constant) & $\begin{array}{r}12,92 \\
4\end{array}$ & $\begin{array}{r}2,2 \\
60\end{array}$ & & $\begin{array}{r}5,7 \\
17\end{array}$ & ,000 \\
\hline $\begin{array}{l}\text { TOTAL_X } \\
1\end{array}$ & , 140 & $\begin{array}{r}, 04 \\
2\end{array}$ & 204 & $\begin{array}{r}3,3 \\
10\end{array}$ & ,001 \\
\hline $\begin{array}{l}\text { TOTAL_X } \\
2\end{array}$ &,- 071 & $\begin{array}{r}, 05 \\
3\end{array}$ &,- 060 & $\begin{array}{r}1,3 \\
22\end{array}$ & 187 \\
\hline $\begin{array}{l}\text { TOTAL_X } \\
3\end{array}$ & 295 & $\begin{array}{r}, 03 \\
7\end{array}$ & ,483 & $\begin{array}{r}7,9 \\
84\end{array}$ & ,000 \\
\hline $\begin{array}{l}\text { TOTAL_X } \\
4\end{array}$ &,- 052 & $\begin{array}{r}, 02 \\
7\end{array}$ &,- 088 & $\begin{array}{r}- \\
1,9 \\
34\end{array}$ & ,054 \\
\hline
\end{tabular}

a. Dependent Variable: TOTAL

Sumber: Output SPSS Versi 22.0

Berdasarkan tabel 4.25 diatas, hasil dari uji statistik $t$ (parsial) akan dijelaskan sebagai berikut:i

1. Hipotesis pertama $\left(\mathrm{H}_{1}\right)$

Variabel pengetahuan etika $\left(\mathrm{X}_{1}\right)$ memiliki nilai $t$ hitung sebesar $3,310>t$ tabel 1,9675, dengan tingkat signifikan sebesar $0,001<0,05$ dan bertanda $(+)$. Menunjukkan bahwa variabel pengetahuan etika berpengaruh positif terhadap persepsi mahasiswa akuntansi mengenai praktik creative accounting, maka hipotesis $\mathrm{H}_{1}$ diterima.

2. Hipotesis kedua $\left(\mathrm{H}_{2}\right)$

Variabel religiusitas $\left(X_{2}\right)$ memiliki nilai t hitung sebesar $-1,322<t$ tabel 1,9675, dengan tingkat signifikan sebesar $0,187>0,05$ dan bertanda (-). Menunjukkan bahwa variabel religiusitas tidak berpengaruh terhadap 
persepsi mahasiswa akuntansi mengenai praktik creative accounting, maka hipotesis $\mathrm{H}_{2}$ ditolak.

3. Hipotesis ketiga $\left(\mathrm{H}_{3}\right)$

Variabel sensitivitas etis $\left(\mathrm{X}_{3}\right)$ memiliki nilai $t_{\text {hitung }}$ sebesar 7,984 $>t_{\text {tabel }} 1,9675$, dengan tingkat signifikan sebesar $0,000<0,05$ dan bertanda (+). Menunjukkan bahwa variabel sensitivitas etis berpengaruh positif terhadap persepsi mahasiswa akuntansi mengenai praktik creative accounting, maka hipotesis $\mathrm{H}_{3}$ diterima.

4. Hipotesis keempat $\left(\mathrm{H}_{4}\right)$

Variabel orientasi etis $\left(X_{4}\right)$ memiliki nilai $\mathrm{t}$ hitung sebesar $-1,934<\mathrm{t}$ tabel 1,9675, dengan tingkat signifikan sebesar $0,054>0,05$ dan bertanda (-). Menunjukkan bahwa variabel orientasi etis tidak berpengaruh terhadap persepsi mahasiswa akuntansi mengenai praktik creative accounting, maka hipotesis $\mathrm{H}_{4}$ ditolak.

\section{Uji Statistik F (Simultan)}

Tabel 16

Hasil Uji Statistik F (Simultan) ANOVA $^{a}$

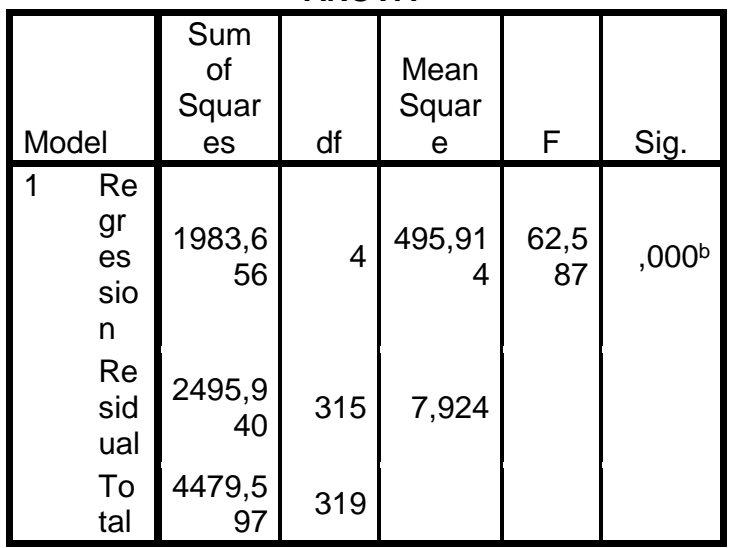

a. Dependent Variable: TOTAL_Y b. Predictors: (Constant), TOTAL $X 4$, TOTAL_X2, TOTAL_X3, TOTAL_X1

Sumber: Output SPSS Versi $22 . \overline{0}$

Berdasarkan tabel 16 di atas dapat dilihat hasil uji statistik $F$ menunjukkan bahwa nilai $F$ sebesar 62,587 untuk $F_{\text {tabel }}$ dengan $(\alpha=0,05)$ diperoleh 2,4003 maka $F$ hitung $>F$ tabel dan nilai signifikansi sebesar $0,000<0,05$. Hasil tersebut menunjukkan bahwa keempat variabel pengetahuan etika, religiusitas, sensitivitas etis, dan orientasi etis berpengaruh secara simultan atau bersama-sama terhadap persepsi mahasiswa akuntansi mengenai praktik creative accounting, maka $\mathrm{H}_{5}$ diterima.

Uji Koefisien Determinasi $\left(\mathbf{R}^{2}\right)$

Tabel 17

Hasil Uji Koefisien Determinasi $\left(\mathbf{R}^{2}\right)$ Model Summary

\begin{tabular}{l|r|r|r|r|}
\hline Model & $\mathrm{R}$ & $\begin{array}{c}\mathrm{R} \\
\text { Squa } \\
\mathrm{re}\end{array}$ & $\begin{array}{c}\text { Adjusted } \\
\text { R Square }\end{array}$ & $\begin{array}{c}\text { Std. Error of } \\
\text { the } \\
\text { Estimate }\end{array}$ \\
\hline 1 & $\begin{array}{r}665 \\
\mathrm{a}\end{array}$ &, 443 &, 436 & 2,815 \\
\hline
\end{tabular}
a. Predictors: (Constant), TOTAL_X4,
TOTAL_X2, TOTAL_X3, TOTAL_X1
Sumber: Output SPSS Versi 22.0

Berdasarkan tabel 17 di atas dapat dilihat bahwa hasil uji koefisien determinasi yang ditunjukan dalam nilai Adjusted $R$ Square sebesar 0,436. Hal tersebut menunjukkan bahwa pengaruh dari variabel pengetahuan etika, religiusitas, sensitivitas etis, dan orientasi etis terhadap persepsi mahasiswa akuntansi mengenai praktik creative accounting sebesar $43,6 \%$. Sedangkan sisanya (100\% - 43,6\%) 56,4\% dipengaruhi oleh variabel lain yang tidak diteliti dalam penelitian ini.

\section{Pembahasan}

\section{Pengaruh Pengetahuan Etika Terhadap Persepsi Mahasiswa Akuntansi Mengenai Praktik Creative Accounting}

Berdasarkan hasil uji statistik yang telah dilakukan menunjukkan bahwa adanya pengaruh dari variabel pengetahuan etika terhadap persepsi mahasiswa akuntansi mengenai praktik creative accounting. Hal tersebut dapat dilihat pada tabel 4.23 pada uji statistik $t$ (parsial) dimana pengetahuan etika $\left(X_{1}\right)$ memiliki nilai $t$ hitung sebesar 3,310 $>t$ tabel 1,9675 , dengan tingkat signifikan sebesar $0,001<0,05$ dan koefisien regresi bertanda (+). Menunjukkan bahwa variabel pengetahuan etika berpengaruh positif terhadap persepsi mahasiswa akuntansi mengenai praktik creative accounting, maka hipotesis $\mathrm{H}_{1}$ diterima.

Tingginya pengetahuan yang dimiliki seseorang akan bermanfaat bagi dirinya sendiri sebagai sebuah solusi atas berbagai masalah serta sebagai acuan dalam bertindak sesuatu. Pengetahuan etika yang dimiliki oleh seseorang akan menjadi acuan 
atau arahan untuk bertindak dan bersikap sesuai dengan etika yang berlaku, yang telah diketahuinya (Aprin, 2018). Dengan demikian mahasiswa akuntansi yang memiliki tingkat pengetahuan etika yang tinggi akan menilai atau menganggap tindakan creative accounting merupakan tindakan tidak etis yang tidak sesuai dengan kode etik akuntan yang berlaku. Dimana hal ini juga ditunjukan dari hasil analisis deskriptif variabel pengetahuan etika bahwa mahasiswa akuntansi di Jawa Barat memiliki tingkat pengetahuan mengenai kode etik akuntan yang tinggi. Dengan memiliki pengetahuan etika yang tinggi akan berguna bagi mahasiswa akuntansi tersebut sebagai calon akuntan.

Hal ini didukung oleh teori atribusi yang menjelaskan bahwa perilaku seseorang ditentukan oleh kombinasi antara faktor internal dan faktor eksternal. Pengetahuan etika merupakan faktor internal dari dalam seseorang karena pengetahuan etika berasal dari kemampuan seseorang untuk memahami kode etik profesi akuntan. Ketika mahasiswa mampu untuk memahami kode etik profesi akuntan maka ia akan menilai tindakan creative accounting merupakan tindakan yang tidak etis. Hasil penelitian ini sejalan dengan penelitian yang dilakukan oleh Aprin (2018), Khomsani dan Ratna (2019), dan Cinthia (2019) yang menyatakan bahwa pengetahuan etika berpengaruh positif terhadap persepsi mahasiswa akuntansi mengenai praktik creative accounting.

\section{Pengaruh Religiusitas Terhadap Persepsi Mahasiswa Akuntansi Mengenai Praktik Creative Accounting}

Berdasarkan hasil uji statistik yang telah dilakukan menunjukkan bahwa tidak ada pengaruh dari variabel religiusitas terhadap persepsi mahasiswa akuntansi mengenai praktik creative accounting. Hal tersebut dapat dilihat pada tabel 4.23 pada uji statistik t (parsial) dimana religiusitas $\left(\mathrm{X}_{2}\right)$ memiliki nilai $\mathrm{t}$ hitung sebesar $-1,322<\mathrm{t}_{\text {tabel }}$ 1,9675, dengan tingkat signifikan sebesar $0,187>0,05$ dan koefisien regresi bertanda (-). Menunjukkan bahwa variabel religiusitas tidak berpengaruh terhadap persepsi mahasiswa akuntansi mengenai praktik creative accounting, maka hipotesis $\mathrm{H}_{2}$ ditolak.
Akan tetapi pada hasil analsis deskriptif variabel religiusitas bahwa mahasiswa akuntansi perguruan tinggi di Jawa Barat memiliki tingkat religiusitas yang tinggi. Hal tersebut bisa terjadi karena seseorang yang paham akan ajaran agama yang dipercayai dan dianutnya belum tentu akan berperilaku baik atau berperilaku etis sesuai dengan aturan agamanya, karena adanya faktor tekanan yang membuat mereka berperilaku tidak etis. Sikap tersebut dijelaskan dalam teori disonansi kognitif, dimana teori ini mengemukakan bahwa perilaku manusia sering tidak sesuai dengan pendapat serta sikapnya atau apa yang dilakukan sering bertentangan dengan keyakinannya atau hati nuraninya sendiri. Seseorang yang seperti ini biasanya lebih cepat menerima persuasi yang seolah-olah membenarkan perilakunya meskipun hati nuraninya sendiri tetap tidak dapat dibenarkan (Setiadi, 2003 dalam Novar, 2008). Maka meskipun mahasiswa akuntansi di Jawa Barat memiliki tingkat religiusitas yang tinggi belum tentu akan memberikan tanggapan terhadap praktik creative accounting itu merupakan tindakan yang tidak etis.

Hasil penelitian ini tidak sejalan dengan penelitian yang dilakukan oleh Aprin (2018), Khomsani dan Ratna (2019), dan Intan Purnama (2019) yang menyatakan bahwa religiusitas berpengaruh positif terhadap persepsi mahasiswa akuntansi mengenai praktik creative accounting.

\section{Pengaruh Sensitivitas Etis Terhadap Persepsi Mahasiswa Akuntansi Mengenai Praktik Creative Accounting}

Berdasarkan hasil uji statistik yang telah dilakukan menunjukkan bahwa adanya pengaruh dari variabel sensitivitas etis terhadap persepsi mahasiswa akuntansi mengenai praktik creative accounting. Hal tersebut dapat dilihat pada tabel 4.23 pada uji statistik $t$ (parsial) dimana sensitivitas etis $\left(X_{3}\right)$ memiliki memiliki nilai $t$ hitung sebesar 7,984 $>t$ tabel 1,9675 , dengan tingkat signifikan sebesar $0,000<0,05$ dan koefisien regresi bertanda (+). Menunjukkan bahwa variabel sensitivitas etis berpengaruh positif terhadap persepsi mahasiswa akuntansi mengenai praktik creative accounting, maka hipotesis $\mathrm{H}_{3}$ diterima. 
Sensitivitas etis akan mempengaruhi seseorang dalam keputusan etis, karena dalam pengambilan suatu keputusan seseorang tersebut akan mempertimbangkan dengan aturan etika yang berlaku, dengan kemampuan sensitivitas etis seseorang akan lebih mudah untuk mengenali dan mengambil pelajaran bahkan cenderung akan menghindari kasus-kasus mengenai praktik creative accounting, maka tingkat sensitivitas etis sangat diperlukan oleh seorang mahasiswa akuntansi sebagai calon akuntan. Mahasiswa akuntansi yang memiliki tingkat sensitivitas etis yang tinggi akan lebih mudah mengenali dan cenderung menghindari praktik creative accounting. Dimana hal ini juga ditunjukan dari hasil analisis deskriptif variabel sensitivitas etis bahwa mahasiswa akuntansi di Jawa Barat memiliki tingkat sensitivitas terhadap perilaku etis yang tinggi.

Hal ini didukung oleh teori atribusi yang menjelaskan bahwa perilaku seseorang ditentukan oleh kombinasi antara faktor internal dan faktor eksternal. Sensitivitas etis merupakan faktor internal dari dalam seseorang karena sensitivitas etis berasal dari kemampuan dalam diri seseorang dengan pengetahuan etika yang dimiliki untuk mengetahui sifat dasar pengambilan suatu keputusan apakah telah sesuai dengan etika yang berlaku atau belum. Hasil penelitian ini sejalan dengan penelitian yang dilakukan oleh Aprin (2018) yang menyatakan bahwa sensitivitas etis berpengaruh positif terhadap persepsi mahasiswa akuntansi mengenai praktik creative accounting.

\section{Pengaruh Orientasi Etis Terhadap Persepsi Mahasiswa Akuntansi Mengenai Praktik Creative Accounting}

Berdasarkan hasil uji statistik yang telah dilakukan menunjukkan bahwa tidak ada pengaruh dari variabel orientasi etis terhadap persepsi mahasiswa akuntansi mengenai praktik creative accounting. Hal tersebut dapat dilihat pada tabel 4.23 pada uji statistik $t$ (parsial) dimana orientasi etis $\left(\mathrm{X}_{4}\right)$ memiliki nilai $\mathrm{t}$ hitung sebesar $-1,934<\mathrm{t}$ tabel 1,9675, dengan tingkat signifikan sebesar 0,054 >0,05 dan koefisien regresi bertanda (-). Menunjukkan bahwa variabel orientasi etis tidak berpengaruh terhadap persepsi mahasiswa akuntansi mengenai praktik creative accounting, maka hipotesis $\mathrm{H}_{4}$ ditolak.

Berdasarkan uji statistika deskriptif pada variabel orientasi etis dengan menggunakan pengujian cluster non hierarki diketahui bahwa sebagian besar mahasiswa akuntansi di Jawa Barat memiliki karakteristik relativisme, hal ini yang menjadi sebab variabel orientasi etis tidak berpengaruh terhadap persepsi mahasiswa akuntansi mengenai praktik creative accounting. Karena karakteristik relativisme tidak terlalu mengindahkan prinsip-prinsip yang ada dan lebih melihat keadaan sekitar sebelum akhirnya bertindak atau merespon suatu kejadian yang melanggar etika. Sesuai dengan teori yang mengatakan bahwa seseorang yang memiliki karakteristik relativisme yang tinggi akan lebih memberikan toleransi dalam menemukan masalah moral serta dalam melaksanakan nilai-nilai universal yang berlaku. Sehingga mahasiswa akuntansi yang memiliki karakteristik relativisme akan menilai atau menganggap praktik creative accounting itu merupakan tindakan yang etis, karena saat dihadapkan kasus tersebut mahasiswa akuntansi lebih melihat keadaan sekitar tanpa mempertimbangkan nilai-nilai etika yang berlaku.

Hasil penelitian ini sejalan dengan penelitian yang dilakukan oleh Intan Saputri (2017) dan Dodik dkk (2019) yang menyatakan bahwa variabel orientasi etis tidak berpengaruh signifikan terhadap persepsi mahasiswa akuntansi mengenai praktik creative accounting. Namun hasil penelitian ini tidak sejalan dengan penelitian yang dilakukan oleh Intan Purnama (2019), Cinthia (2019), dan May Diana (2018) yang menyatakan bahwa variabel orientasi etis berpengaruh positif terhadap persepsi mahasiswa akuntansi mengenai praktik creative accounting.

\section{Pengaruh Pengetahuan Etika, Religiusitas, Sensitivitas Etis, dan Orientasi Etis Terhadap Persepsi Mahasiswa Akuntansi Mengenai Praktik Creative Accounting}

Berdasarkan hasil uji statistik yang telah dilakukan menunjukkan bahwa adanya pengaruh dari variabel 
pengetahuan etika, religiusitas, sensitivitas etis, dan orientasi etis terhadap persepsi mahasiswa akuntansi mengenai praktik creative accounting. Hal tersebut dapat dilihat pada tabel 4.24 pada uji statistik $F$ (simultan) yang menunjukkan bahwa nilai signifikansi untuk variabel pengetahuan etika, religiusitas, sensitivitas etis, dan orientasi etis sebesar $0,000<0,05$. Hasil tersebut menunjukkan bahwa keempat variabel yaitu pengetahuan etika, religiusitas, sensitivitas etis, dan orientasi etis berpengaruh secara simultan atau bersama-sama terhadap persepsi mahasiswa akuntansi mengenai praktik creative accounting, maka $\mathrm{H}_{5}$ diterima.

\section{KESIMPULAN DAN SARAN}

\section{Kesimpulan}

Berdasarkan hasil analisis data dan pembahasan dari masing-masing variabel yang terlah dibahas di bab sebelumnya, maka dapat disimpulkan bahwa:

1. Pengetahuan etika berpengaruh positif terhadap persepsi mahasiswa akuntansi mengenai praktik creative accounting. Pengetahuan etika yang dimiliki oleh seseorang akan menjadi acuan atau arahan untuk bertindak dan bersikap sesuai dengan etika yang berlaku, yang telah diketahuinya. Dengan demikian mahasiswa akuntansi yang memiliki tingkat pengetahuan etika yang tinggi akan menilai atau menganggap tindakan creative accounting merupakan tindakan tidak etis yang tidak sesuai dengan kode etik akuntan yang berlaku.

2. Religiusitas tidak berpengaruh terhadap persepsi mahasiswa akuntansi mengenai praktik creative accounting. Namun pada hasil statistika deskriptif variabel religiusitas menunjukkan bahwa mahasiswa akuntansi di Jawa Barat mempunyai tingkat religiusitas yang tinggi. Hal tersebut bisa terjadi karena seseorang yang paham akan ajaran agama yang dipercayai dan dianutnya belum tentu akan berperilaku baik atau berperilaku etis sesuai dengan aturan agamanya, karena adanya faktor tekanan yang membuat mereka berperilaku tidak etis. Maka meskipun mahasiswa akuntansi di Jawa Barat memiliki tingkat religiusitas yang tinggi belum tentu akan memberikan tanggapan terhadap praktik creative accounting itu merupakan tindakan yang tidak etis.

3. Sensitivitas etis berpengaruh positif terhadap persepsi mahasiswa akuntansi mengenai praktik creative accounting. Sensitivitas etis akan mempengaruhi seseorang dalam keputusan etis, karena dalam pengambilan suatu keputusan seseorang tersebut akan mempertimbangkan dengan aturan etika yang berlaku, dengan kemampuan sensitivitas etis seseorang akan lebih mudah untuk mengenali dan mengambil pelajaran bahkan cenderung akan menghindari kasuskasus mengenai praktik creative accounting, maka tingkat sensitivitas etis sangat diperlukan oleh seorang mahasiswa akuntansi sebagai calon akuntan.

4. Orientasi etis tidak berpengaruh terhadap persepsi mahasiswa akuntansi mengenai praktik creative accounting. Karena sebagian besar mahasiswa akuntansi di Jawa Barat memiliki karakteristik relativisme, hal ini yang menjadi sebab variabel orientasi etis tidak berpengaruh terhadap persepsi mahasiswa akuntansi mengenai praktik creative accounting. Karena karakteristik relativisme tidak terlalu mengindahkan prinsip-prinsip yang ada dan lebih melihat keadaan sekitar sebelum akhirnya bertindak atau merespon suatu kejadian yang melanggar etika.

5. Pengetahuan etika, religiusitas, sensitivitas etis, dan orientasi etis berpengaruh secara simultan atau bersama-sama terhadap persepsi mahasiswa akuntansi mengenai praktik creative accounting. Dapat disimpulkan bahwa semua variabel tersebut dapat mempengaruhi persepsi mahasiswa akuntansi mengenai praktik creative accounting.

\section{Saran}


Berdasarkan kesimpulan yang telah diuraikan di atas, Penulis mencoba memberikan saran yang diharapkan dapat bermanfaat dan dapat memberikan masukan yang positif, antara lain sebagai berikut:

1. Bagi Mahasiswa Akuntansi

Sebagai calon akuntan di masa depan, sebaiknya mahasiswa akuntansi membekali diri dengan kemampuan dan pengetahuan yang tinggi serta etika yang baik agar dapat menjadi seorang akuntan yang kompeten, profesional, dan memiliki etika yang baik.

2. Bagi Peneliti Selanjutnya

a. Untuk peneliti selanjutnya dapat menambah jumlah sampel atau memperluas jangkauan sampel tidak hanya mahasiswa akuntansi di perguruan tinggi di Jawa Barat saja, seperti memperluas jangkauan ke mahasiswa akuntansi di DKI Jakarta dan provinsi Banten, atau ke mahasiswa akuntansi di pulau Jawa.

b. Peneliti selanjutnya sebaiknya menambah variabel baru atau mengganti variabel yang ada di penelitian ini yang dapat berpengaruh terhadap persepsi mahasiswa akuntansi mengenai praktik creative accounting dari faktor eksternal individu seperti lingkungan atau sistem teknologi, karena dalam penelitian ini hanya meneliti faktor internal individu.

c. Menambah metode pengumpulan data seperti wawancara agar dapat mencerminkan perseps responden yang lebih akurat.

3. Bagi Lembaga Pendidikan

Perlu pengembangan kurikulum akuntansi terkait dengan permasalahan etika, agar bisa meningkatkan persepsi mahasiswa terkait dengan kasus atau masalah tentang etika khususnya kasus atau praktik creative accounting, tidak hanya membahas ke segi fraud saja.

\section{KETERBATASAN}

Penelitian ini telah dilaksanakan sesuai dengan prosedur ilmiah, namun masih memiliki keterbatasan, yaitu:

1. Kuesioner dalam penelitian ini disebarkan secara online menggunakan Google Form dan diisi secara online oleh responden, oleh karena itu peneliti tidak bisa mengontrol jawaban responden secara langsung, maka dimungkinkan adanya bias dalam pengisian kuesioner.

2. Dalam penelitian ini data yang dihasilkan hanya dari instrumen kuesioner yang didasarkan pada persepsi jawaban responden, sehingga kesimpulan yang diambil hanya berdasarkan data yang dikumpulkan melalui instrumen kuesioner tanpa dilengkapi dengan wawancara.

\section{REFERENCES}

Agustia, D. \& A. Palupi. (2012). Praktik Creative accounting Pada Koperasi di Jawa Timur. Jurnal Ekonomi dan Keuangan.

Amat, Blake dan Dowd. 1999. The Ethics of Creative

EconomicsWorkingPaper,

Desember 1999.MAKSIMUM, 9(2).

Anggita, M. Y. C., \& Sari, R. C. (2018). Pengaruh Orientasi Etis, Tingkat Pengetahuan Akuntansi, dan Jenis Perguruan Tinggi terhadap Persepsi Etis Mahasiswa Akuntansi mengenai Praktik Creative accounting. Jurnal Profita: Kajian Ilmu Akuntansi, 6(1).

Arfan, Lubis Ikhsan. 2011. Akuntansi Keperilakuan, cetakan kedua. Jakarta: Salemba Empat.

Asprilliadita, A., \& Aisyah, M. N. (2019). Pengaruh Pengetahuan Etika, Religiusitas, Dan Sensitivitas Etis Terhadap Persepsi Mahasiswa Akuntansi Mengenai Praktik Creative Accounting. 
Jurnal Profita: Kajian IImu Akuntansi, 7(3).

Astuti, R., \& Sugiharto, B. Pengaruh Locus of Control, Ethical Sensitivity, Kecerdasan Intelektual, Kecerdasan Emosional, Kecerdasan Spiritual dan Tingkat Pendidikan Terhadap Perilaku Etis. Jurnal ASET (Akuntansi Riset), 11(2), 256270.

Balaciu, D., \& Pop, C. M. (2008). Is creative accounting a form of manipulation. Annals of the University of Oradea, Economic Science eries, 17(3), 935-940.

Cahrles T.Horngren dan Walter T.Harrison.2007.Akuntansi Jilid 1, Edisi ke- 7.Jakarta: Penerbit Erlangga.

Falah, S. (2006). Pengaruh Budaya Etis Organisasi dan Orientasi Etika Terhadap Sensitivitas Etika (Studi Empiris Tentang Pemeriksaan Internal di Bawasda Pemda Papua) (Doctoral dissertation, Program Pasca Sarjana Universitas Diponegoro).

Fitria, M., \& Sari, V. F. (2014). Pengaruh Orientasi Idealisme, Relativisme, Tingkat Pengetahuan Akuntansi, Dan Gender Terhadap Persepsi Mahasiswa Akuntansi Tentang Krisis Etika Akuntan Profesional (Studi Empiris Mahasiswa Akuntansi Perguruan Tinggi di kota Padang). Wahana Riset Akuntansi, 2(1), 387-404.

Ghozali, Imam. 2013. Aplikasi Analisis Multivariate dengan Program IBM SPSS 21 Update PLS Regresi. Semarang: Badan Penerbit Universitas Diponegoro.

Glock, C. Y., \& Stark, R. (1965). Religion and Society in Tension. Chicago: Rand McNally.

Greenfield, Jr., Carolya Strand Norman, and Benson Wier. (2007). The Effect of Ethical Orientation and Professional Commitmen on Earnings Management Behavior.
Journal of Business Ethics. Springer.

Gulo, W. 2007. Metodologi Penelitian. Jakarta : Grasindo.

Henry, K. (2013). Perbedaan Persepsi Etis Dosen Akuntansi Terhadap Praktik Earnings Management di Kota Pekanbaru dalam Perspektif Gender. Marwah, Vol. XXI, No. 2.

https://jordyayal.wordpress.com, 2016

https://sumsel.antaranews.com

Hutahahean, M. U. B., \& Hasnawati, H. (2015). Pengaruh Gender, Religiusitas Dan Prestasi

Belajar Terhadap Perilaku Etis Akuntan Masa Depan (Studi Pada Mahasiswa Akuntansi Perguruan Tinggi Swasta Di Wilayah Dki Jakarta). Jurnal Akuntansi Trisakti, 2(1), 49-66.

Jaya, I. P., \& Sukirno, S. (2020). The Effect of Religiosity and Ethical Orientation on Perceptions of Undergraduate Accounting Students on Creative accounting. Jurnal Dinamika Akuntansi, 12(1), 68-76.

Juliardi, D., Bavana, M., \& Firdaus, M. I. (2020, March). Factors Affecting Accounting Students' Perception About Creative accounting Study on Accounting Students in Economic of Faculty Universitas Negeri Malang. In 4th Padang International Conference on Education, Economics, Business and Accounting ( PICEEBA-2 2019) (pp. 58-67). Atlantis Press.

Kamiński, R. (2014). Creative accounting Does not Need to Equal Falsification of Accounts. Journal of Economics World, 2(4), 272-280.

Kartika, Andi. (2013). Perbandingan Sensitivitas Etis Antara Mahasiswa Akuntansi Pria dan Wanita serta Mahasiswa Akuntansi dan Manajemen. Jurnal 
Dinamika Akuntansi, Keuangan dan Perbankan, Vol. 2, No. 1. Universitas Stikubank.

Kasiram, Moh. 2008. Metodologi Penelitian. Malang: UIN-Malang Pers.

Kharismawati, K., \& Sari, R. C. (2019). Pengaruh Ethical Framework, Pengetahuan Etika Dan Religiusitas Terhadap Persepsi Etis Mengenai Praktik Creative accounting. Jurnal Profita: Kajian IImu Akuntansi, 7(8).

Khomsiyah, dan N. Indriantoro. (1998). Pengaruh Orientasi Etika terhadap Komitmen dan Sensitivitas Etika Auditor Pemerintah di DKI Jakarta (The Influence of Ethical Orientation on Commitment and Ethical Sensitivity of Government Auditors in DKI Jakarta). Jurnal Riset Akuntansi Indonesia(Indonesian Accounting Research Journal), Vol.1 Januari, p. 13-28.

Kurniawan, A., \& Anjarwati, A. (2020, March). Does Love of Money, Machiavellian, Religiosity, Socioeconomic Status, and Understanding of the

Accountant's Code of Ethics Affect the Ethical Perception of Accounting Students?. In 1st International Conference on Accounting, Management and Entrepreneurship (ICAMER 2019) (pp. 33-37). Atlantis Press.

Mangiskar, L. (2019). Analisis Pengaruh Kecerdasan Emosional, Kecerdasan Spiritual, dan Love of Money Terhadap Persepsi Etis Mahasiswa Akuntansi Mengenai Etika profesi Akuntan (Studi Kasus Pada Universitas Swasta Jurusan Akuntansi Kota Semarang).

Maryani, T., \& Ludigdo, U. (2001). Survei atas faktor-faktor yang mempengaruhi sikap dan perilaku etis akuntan. Jurnal Tema, 2(1), 49-62.
Nasution, M.N. (2008). Analisis Pembentukan Disonansi Kpgnitif Konsumen Pemilik Mobil Isuzu Panther Pada PT Isuindomas Putra Medan. Skripsi. Universitas Sumatera Utara.

Odia, J. O., \& Ogiedu, K. O. (2013). Corporate governance, regulatory agency and creative accounting practices in Nigeria. Mediterranean Journal of Social Sciences, 4(3), 55.

Pemayun, A. W., \& Budiasih, I. G. A. N. (2018). Pengaruh religiusitas, status sosial ekonomi dan love of money pada persepsi etis mahasiswa akuntansi. EJurnal Akuntansi, 23(2), 16001628.

Pesireron, S. (2018). Pengaruh Keterampilan, Jobb Stress Dan Disiplin Kerja Terhadap Kinerja Auditor Inspektorat (Study Empiris Pada Inspektorat Kabupaten Seram Bagian Timur dan Kabupaten Maluku Tengah). Jurnal Maneksi, 5(1), 26-31.

Priambudi, F. R., \& Sukanti, S. (2016). Pengaruh Sensitivitas Etika Terhadap Persepsi Mahasiswa Atas Perilaku Etis Akuntan (Studi Kasus Pada Mahasiswa Akuntansi Universitas Negeri Yogyakarta). Jurnal Profita: Kajian IImu Akuntansi, 4(4).

Pudjawidjana. (1983). Model - Model Pembelajaran. Yogyakarta : Pustaka.

Rahayu, S., \& Sari, R. C. (2018). Pengaruh Gender, Pengetahuan Etika Profesi Akuntan, Dan Jenis Perguruan Tinggi Terhadap Persepsi Mahasiswa Akuntansi Mengenai Creative Accounting. Jurnal Profita: Kajian IImu Akuntansi, 6(4).

Renaldo, M. (2012). Penerapan Akuntansi Pada Usaha Kecil Menengah. Jurnal Akuntansi, 1 ( 2), 57-62. Robbins, R., Glock, CY, \& Stark, $\mathrm{R}$. 
Robbins, Stephen P. (2006). Perilaku Organisasi, Edisi Kesepuluh. Jakarta: PT Indeks Kelompok Gramedia.

Roberts, J., \& Scapens, R. (1985). Sistem Akuntansi dan Sistem Akuntabilitas Pemahaman Praktik Akuntansi Dalam Konteks Organisasi Mereka. Akuntansi, Organisasi dan Masyarakat, 10 ( 4), 443-456.

Saputri, I., \& Sari, R. C. (2018). Pengaruh Orientasi Etis, Gender, Dan Jenis Perguruan Tinggi Terhadap Persepsi Mahasiswa Akuntansi Mengenai Praktik Creative accounting. Jurnal Profita: Kajian Ilmu Akuntansi, 6(1).

Sari, M. Pengaruh orientasi etika dan pengalaman terhadap sensitivitas etika auditor internal dengan komitmen profesional sebagai variabel intervening: Studi pada Perusahaan Manufaktur Oil and Gas Swasta di DKI Jakarta.

Scott, William R. (2000). Financial Accounting Theory.USA:PrenticeHall.

Somantri, H. (2011). Memahami Akuntansi. Bandung: Armico.

Sugiyono. (2016). Metode Penelitian Kuantitatif, Kualitatif dan R\&D. Bandung: Alfabeta.

Sugiyono. (2004). Metode Penelitian.Bandung: Alfabeta.

Sugiyono. (2018). Metode Penelitian Kombinasi (Mixed Methods).Bandung: CV Alfabeta.

Sukrisno, Agoes dan Ardana, I. C. (2009). Etika Bisnis dan Profesi:
Tantangan Membangun Manusia Seutuhnya. Jakarta: Salemba Empat.

Sulistiawan Dheny, dkk. (2011). Creative accounting: Mengungkap managemen laba dan skandal akuntansi. Jakarta: Salemba Empat.

Sulistiawan, D. (2006). "Persepsi Komunitas Akuntansi Terhadap Praktik Creative Accounting". Akuntansi dan Teknologi Informasi, Vol. 5, No.2,hlm115128.

Uma Sekaran. (2006). Metode Penelitiaan Bisnis. Jakarta: Salemba Empat.

Usurelu, Valentin loan, et al. (2010). "Accounting Ethics Responsibility Versus Creativity." Annals of the University of Petrosani, Economics. 10, hlm 349356.

Valentine Rahajaan, Cinthia (2019). Analisis Faktor-Faktor Yang Mempengaruhi Persepsi Mahasiswa Akuntansi Mengenai Creative accounting (Studi Kasus Mahasiswa Akuntansi Universitas Kristen Duta Wacana). Bachelor Thesis, Universitas Kristen Duta Wacana.

Velasquez, M. G., \& Rostankowski, C. (Eds.). (1985). Ethics, theory and practice. Prentice Hall.

Wati, M., \& Sudibyo, B. (2016). Pengaruh pendidikan etika bisnis dan religiusitas terhadap persepsi etis mahasiswa akuntansi. Jurnal Economia, 12(2), 183-201. 